Review (総 説)

$$
\begin{gathered}
\text { アラン・オーストン基礎資料 } \\
\text { 川田伸一郎 }^{1}
\end{gathered}
$$

\title{
Biographic Review of Alan Owston
}

\begin{abstract}
Shin-ichiro Kawada ${ }^{1}$
Abstract. Alan Owston is one of the most famous naturalists of the Meiji Period in Japan. His contribution to natural history knowledge was briefly introduced in previous literature, however, no detailed biographic and bibliographic information was made available. This review compiles his achievements within both industrial and natural history contexts, drawing upon information obtained from academic publications, reports of research organizations and public newspaper articles. It pays especial attention to his friendships with contemporary specialists in several fields around the world, and also his employees, including specimen collectors of his company 'Alan Owston' at Yokohama. The author hopes this review will provide a basic data set of his life as a background to understanding the development of Japanese technological and biological research during the Meiji Period.
\end{abstract}

Key words: Merchant, Natural history dealer, Ornithology, Yacht.

キーワード：貿易商, 自然史標本ディーラー, 鳥類学, ヨット.

\section{はじめに}

日本の自然史研究の黎明期を解読するにあたり，アラン・オーストン（Alan Owston）は欠か せない人物である。明治から大正初期に横浜で貿易商として会社経営したオーストンは, 自然 史標本の収集家としてもよく知られており, 多くの学名にその名を献名されている。特に鳥類 分野において, オーストンは精力的な収集活動を行い, 多数の標本が国内外の研究機関に送ら れたとされ, 標本に基づいて「owstoni」の種小名, 亜種小名を与えられた分類群は数多 い（Weintraub 1998）。オーストンオオアカゲラ，オーストンウミツバメ，オーストンヤマガラ といった和名においても，鳥類学への貢献を伺うことができる。

ところが現在までにオーストンの活躍を記した文献はわずかであり，そのほとんどはオース トンの死後，永澤（1916）によって書かれた追悼文から引用されたものである。磯野（1988）は 東京帝国大学理科大学附属三崎臨海実験所（以下三崎臨海実験所あるいは三崎とする）の歴史

Received 18 March 2015, Revised 7 August 2015, 2nd Revision 24 September 2015, 3rd Revision 15 October 2015, Accepted 30 November 2015.

1 国立科学博物館動物研究部, †305-0005 茨城県つくば市天久保4-1-1. E-mail: kawada@kahaku.go.jp

1 Department of Zoology, National Museum of Nature and Science, 4-1-1, Amakubo, Tsukuba, Ibaraki 3050005, Japan. E-mail: kawada@kahaku.go.jp 
的研究において，オーストンについても独自の調査に基づいて記しているが，主に水産分野の 自然史的な側面からの内容からなり，オーストンが日本で活動した約 50 年の一部についてし か明らかにされていないのが現状である。オーストンが国内外の生物学に与えた影響は鳥類学 のみならず多岐にわたる分類群に及ぶ可能性があり, 彼の活動全般について精査することは鳥 類学における貢献を補足かつ再評価するものであると考えられる。

筆者はこれまでに文献上知られるオーストンの活動について調査してきた。オーストンの死 後100年を経て情報が希薄になりつつある現在，これまでに調べた成果をここにまとめて，今 後のオーストン研究のための基礎資料とすることが，本稿の目的である。

\section{1）初期の活動}

アラン・オーストンは 1853 年 8 月 7 日に英国サリー州パーブライト（Pirbright, Surrey）で生ま れた。父はこの地で 40 年にわたり司教代理の地位にあった聖職者フランシス（Francis Owston), 母はエリザ・ニー・ステッドマン（Eliza Nee Stedman；旧姓）で, 後にオーストン を追って来日することとなる兄のフランシス（Francis Owston）と妹のバーサ（Bertha Owston） を含む 5 人家族だった (http://www.craigfamilytree.com/html/owston.html)（以下，父と兄に関して はアラン・オーストンを示す「オーストン」と区別して，「父フランシス」および「兄フラン シス」と表記する)。1871年までにハーストピアポイント（Hurstpierpoint）のセント・ジョン ズ・カレッジ (St. Johns College) で教育を受けた記録が紹介されているが (Spencer Jones et al. 2011), その専門性等については不明である。1871年頃，オーストンはレーン・クロ フォード商会 (Lane Crowford \& Co.) の一員として, 清国上海にいたといわれるが, 半年ほど で横浜へ移動した（磯野 1988）。

ここでは同時代の横浜外国人居留地での会社情報を掲載した「幕末明治在日外国人・機関名 鑑 JAPAN DIRECTORY」（以下JDとする）を基に，オーストンの商人としての活動を見てい きたい。なお，JDは通常毎年1月に公表されたものをその年の巻として出版していたとされ る。そのため本論文ではJD掲載巻の前年の情報として取り扱うこととする。

オーストンはレーン・クロフォード商会の社員として1873年から名前が確認できるので（立 脇 1996a)，1872年に横浜の支社に勤務となり来日したと考えられる。レーン・クロフォード 商会はトーマス・アッシュ・レーン（Thomas Ash Lane）とニニアン・クロフォード（Ninian Crawford）が1850年に香港に開いた商社で，もともとは船員のためのパンやビスケットまたは その原料である小麦といった生活必需品や多少の贅沢品を报うのが業務内容だったようだが, 後に様々な物品の輸出入を手掛けるようになった（Nugent 1982）。横浜に支店を開設したのが 1871 年のようである。JDによると, 当時レーン・クロフォード商会は横浜居留地59-C番に所 在し，9名が名簿に確認できる（立脇 1996a）。オーストンはこのうち5番目に名前があるの で，会社内での地位はそれほど低くなかったと考えられる。

この頃のオーストンの様子を知る記述として, 磯野（1988）は「1873年（明治6年）頃横浜 山下町で牧場を経営, 外国人居留地に牛乳を配達していたとの記録がある」と記している。こ れは『開港時代文化伝来史話』（伊藤 1937）がもとになっていると思われる。同書の「牛乳 の章にはオーストンが「明治六七年の頃米国より長角牛のデボン系雑種三十余頭を輸入し其外 数十頭を擁する牧場を根岸不動坂に新設し, 主として居留外人相手の搾乳業を経営したが, 間 
もなく其内の五十頭を東京小石川老松町の細川候邸内の牧場に移している」とある。この酪農 業はレーン・クロフォード商会の業務としては考えられなくもないが，真偽のほどはいかがな ものだろう。

もう一つこの時代の足跡として，1872年に設立された日本アジア協会 (Asiatic Society of Japan）の機関誌 Transaction of the Asiatic Society of Japanの創刊号（1874年）から6号（1878年） の間，会員名簿に「A. Owston」の名前があることである（Asiatic Society of Japan 1874, 1878）。 日本アジア協会は英国の外交官として知られるアーネスト・サトゥ（Ernest Satow）らにより設 立された団体で, 開国後の日本研究を推進することを目的とした。オーストンは 1877 年まで レーン・クロフォード商会の一員だったことを鑑みると, 商会員として参加していたのか, あ るいは個人的な興味関心から参加したのかは定かではない。少なくともオーストンが名簿以外 の文章や記事で登場することは全くないようである。余談ではあるが，オーストンと同時代に 来日し, 自然史資料収集を行ったヘンリー・プライア（Henry Pryer）もこの協会員となってお り, 創立時は委員会の「Curator and Librarian」の地位にあった。こちらは日本の鱗翅類などに 関する文章を掲載している（例えばPryer 1883-1885）。

オーストンは 1877 年にレーン・クロフォード商会と同番地のE. C. カービー商会 (E. C. Kirby \& Co.) へ異動したことがJDから見て取れる（立脇 1996b; なおカービー商会は1860年代 には居留地 85 番にあった)。この商社はエドワード・チャールズ・カービー (Edward Charles Kirby）が興した会社で, 鉄鋼関係の輸入業だったらしい。この頃オーストンがカービー商会 に在籍したことを示すもう一つの資料として, 北海道開拓使の「G. Noguchi」（加藤（2006）に 詳しい野口源之助のことと思われる）に宛てた 1877 年9月 25 日付オーストンの署名入り手紙 が北海道大学附属図書館に存在する（資料請求番号：E. C. Kirby \& Co. 001）。内容は「液状ア スファルト在庫なし」とのことなので，道路建設などの業務にもかかわっていたのであろう。

翌年の 1878 年, オーストンはさらに所属先を居留地 86 番の「The Christian Association」及び 「Temperance Hall」へと変更している（立脇 1996c）。オーストンの宗教信仰について知られて いないが, 父がパーブライトの司教代理の職にあったこと, 及びこの所属からキリスト教の信 者であった可能性がうかがえる。この時期, 8年間の商社ビジネスマンとして経験を積んだ彼 は，独立を目指して準備していたのであろうと思われる。そして1879年についに彼は社名を 「Alan Owston」とする会社を設立して独立することとなる（立脇 1996c）。これが後によく知 られたオーストン商会の誕生である。

\section{2) オーストン関連会社の変遷}

\section{2)-1. オーストンの共同経営者}

1879年（明治12年）, オーストンは居留地179-B番にオーストン商会（JDの欧文記述では 「179-B Alan Owston」) を設立した。当初 2 年間はJDに本人のみが構成員として挙げられてお り（Table 1)，およそすべての業務を取り仕切っていたと思われる。業務内容は「Commission Merchant \& General Importer」としており, 輸入品の代理販売店のようなものであろう。また $\lceil$ Special attention paid to the selection and purchase of all kinds of Japanese wares.」とも記されてい るので，さまざまな日本の物産を輸出する業務も行っていたと考えられる（立脇 1996c）。翌 年のJDからは広告欄に「ALAN OWSTON GENERAL IMPORTER No. 179」という簡単な広告 
Table 1. List of personnel working for Owston \& Co. (Owston, Snow \& Co. from 1881 to 1884) based on JAPAN DIRECTORY.

表1。「幕末明治在日外国人・機関名鑑 JAPAN DIRECTORY」に基づくオーストン商会（1881年か ら 1884 年はオーストン・スノー商会）のメンバーリスト.

\begin{tabular}{|c|c|c|}
\hline Year & $\begin{array}{l}\text { House } \\
\text { number }\end{array}$ & Member \\
\hline 1879 & 179 & Alan Owston \\
\hline 1880 & 179 & Alan Owston \\
\hline 1881 & 179 & Alan Owston, H. J. Snow, Imamura Genzo \\
\hline 1882 & 179 & Alan Owston, H. J. Snow, A. J. M. Smith, Imamura Genzo, Osa Masamichi \\
\hline 1883 & 179B & Alan Owston, H. J. Snow, A. J. M. Smith, Imamura Genzo, Osa Masamichi \\
\hline 1884 & $179 \mathrm{~B}$ & Alan Owston, H. J. Snow, A. J. M. Smith, A. Elfen, Imamura Genzo, Osa Masamichi \\
\hline 1885 & $179-\mathrm{B}$ & Alan Owston \\
\hline 1886 & $179-\mathrm{B}$ & Alan Owston \\
\hline 1887 & 179-B & Alan Owston, Imamura Genzo, Osa Masamichi \\
\hline 1888 & $179-\mathrm{B}$ & Alan Owston, Francis Owston, Imamura Genzo, Osa Masamichi \\
\hline 1889 & $179-\mathrm{B}$ & Alan Owston, Francis Owston, Imamura Genzo, Osa Masamichi \\
\hline 1890 & 179-B & Alan Owston, Francis Owston, Imamura Genzo, Osa Masamichi \\
\hline 1891 & $179-\mathrm{B}$ & Alan Owston, Francis Owston, Imamura Genzo, Osa Masamichi \\
\hline 1892 & 179-B & Alan Owston, Osa Masamichi \\
\hline 1893 & $179-\mathrm{B}$ & Alan Owston, Osa Masamichi, Fujioka Motojiro, Fujie Goro, Furusawa Genji, Cho Otome \\
\hline 1894 & 179-A & $\begin{array}{l}\text { Alan Owston, A. Iizuka, Osa Masamichi, Fujioka Motojiro, Fujie Goro, Furusawa Genji, } \\
\text { Okazaki Riuichi, Tanabe Kitaro, Era Motomichi }\end{array}$ \\
\hline 1895 & 179-A & $\begin{array}{l}\text { Alan Owston, Osa Masamichi, A. Iizuka, F. Yamamoto, C. Yamamoto, Fujioka Motojiro, } \\
\text { Furusawa Genji, Okazaki Riuichi, Aoyagi Shinkichi, Tanabe Kitaro, Era Motomichi, } \\
\text { Kawamura Shigetaro, Kikuchi Seusaku }\end{array}$ \\
\hline 1896 & $179-\mathrm{A}$ & $\begin{array}{l}\text { Alan Owston, Osa Masamichi, A. Iizuka, F. Yamamoto, C. Yamamoto, Fujioka Motojiro, } \\
\text { Okazaki Riuichi, Aoyagi Shinkichi, Tanabe Kitaro, Era Motomichi, Murao Kiyoshi }\end{array}$ \\
\hline 1897 & 179-A & Alan Owston, F. Yamamoto, C. Yamamoto, Fujioka Motojiro, Murao Kiyoshi \\
\hline 1898 & 179-A & Alan Owston, F. Yamamoto, C. Yamamoto, Osa Masamichi, Ishii Masazo \\
\hline 1899 & $179-\mathrm{A}$ & Alan Owston, C. Yamamoto, S. Cho, M. Ishii, K. Kita, H. Cho \\
\hline 1900 & $179-\mathrm{A}$ & Alan Owston, C. Yamamoto, S. Cho, K. Kita, H. Cho, K. Miyamaye \\
\hline 1901 & 179-A & Alan Owston, S. Cho, K. Kita, H. Cho, S. Kato, T. Tsurumaru, S. Tominaga, K. Nagayo \\
\hline 1902 & $179-\mathrm{A}$ & Alan Owston, G. Charlesworth Jr., S. Cho, H. Cho, S. Tominaga, H. Nakamura, K. Nagayo \\
\hline 1903 & $179-\mathrm{A}$ & Alan Owston, G. Charlesworth Jr., S. Cho, H. Cho, S. Tominaga, H. Nakamura, K. Nagayo \\
\hline 1904 & $179-\mathrm{A}$ & $\begin{array}{l}\text { Alan Owston, G. Charlesworth Jr., S. Cho, H. Cho, S. Tominaga, H. Nakamura, H. Santer, } \\
\text { K. Nagayo, M. Aihara, T. Takebayashi, Y. Ota, R. Osada }\end{array}$ \\
\hline 1905 & 224 & $\begin{array}{l}\text { Alan Owston, G. Charlesworth Jr., S. Cho, H. Cho, S. Tominaga, H. Nakamura, K. } \\
\text { Nagayo, M. Aihara, T. Takebayashi, Y. Ota, R. Osada, R. Yamamoto }\end{array}$ \\
\hline 1906 & 224 & $\begin{array}{l}\text { Alan Owston, G. Charlesworth Jr., W. A. Morris, S. Cho, H. Cho, K. Nagayo, T. Take- } \\
\text { bayashi, Y. Ota }\end{array}$ \\
\hline 1907 & 224 & $\begin{array}{l}\text { Alan Owston, G. Charlesworth Jr., W. A. Morris, S. Cho, H. Cho, K. Nagayo, S. Seki, T. } \\
\text { Takebayashi, Y. Miyasaka }\end{array}$ \\
\hline 1908 & 224 & $\begin{array}{l}\text { Alan Owston, G. Charlesworth Jr., W. A. Morris, S. Cho, H. Cho, K. Nagoya*, S. Seki, T. } \\
\text { Takebayashi }\end{array}$ \\
\hline 1909 & 224 & $\begin{array}{l}\text { Alan Owston, G. Charlesworth Jr., W. A. Morris, S. Cho, H. Cho, K. Nagoya*, S. Seki, T. } \\
\text { Takebayashi }\end{array}$ \\
\hline 1910 & 224 & Alan Owston, G. Charlesworth, H. Cho, T. Takata, E. Heidkamper, T. Yamada \\
\hline 1911 & 224 & Alan Owston, G. Charlesworth, H. Cho, Y. Takata, E. Heidkamper, T. Yui \\
\hline 1912 & 224 & Alan Owston, G. Charlesworth, H. Cho, Y. Takata, T. Yui \\
\hline 1913 & 224 & Alan Owston, G. Charlesworth, H. Cho, T. Yuki \\
\hline 1914 & 224 & Alan Owston, H. Cho, T. Yuki \\
\hline 1915 & $21-\mathrm{C}$ & H. Cho, T. Yuki \\
\hline
\end{tabular}

* [sic], probably misspelling of “K. Nagayo”.

*原文ママ,「K. Nagayo」のミススペルと考えられる。 
記事も掲載されている（立脇 1996d）。また，この頃Shimada Rei という女性と最初の結婚をし て, 一人の娘 (Susie) が生まれたことが知られている (http://www.meiji-portraits.de/)。

会社設立から 3 年目の 1881 年, 社名はオーストン・スノー商会（JDの欧文記述では $「$ Owston, Snow \& Co.」）と変更された（立脇 1996d；Table 1)。「Snow」というのは千島列島周 辺で当時アザラシ類やラッコEnhydra lutris の毛皮猟を行っていた英国人ヘンリー・ジェーム ス・スノー (Henry James Snow) である。スノーは20歳の頃来日して, 4 年ほどは鉄道建設の 技師として働いていた（スノー 1980；所収の犬飼哲夫による序文も参照のこと）。スノーが 1910年に著した『In Forbidden Seas』では彼がロシア近海でかなり無謀なラッコ猟を行ってい た様子が記されている（Snow 1910）。1870年代は主に函館を拠点として活動していたようで, 当時来日していたトーマス・ブラキストン（Thomas Blakiston）と交流を深める場面もある。同 年代終わり頃から拠点は横浜となっており, オーストンと共同経営に乗り出した 1881 年には, 千島列島のスレデノイ岩礁で新しいオットセイ類の群生地を発見して，2,400枚に及ぶ毛皮を 入手している。オットセイ猟は数年間好調であったが, 1883 年にロシア船に拿捕される事件 があり，またその翌年にはラッコとオットセイの資源の枯渇に関する記述があることは，この のちに会社から退くことと関係があるのかもしれない。スノーがいつまで日本にいたのかは不 明であるが，少なくとも『Notes on the Kuril Islands』（Snow 1897）という資料を出版した1897 年には横浜にいたようだ。これはスミソニアン図書館に保管されている同書が当時の脊椎動物 研究者であるレナード・スタイネガー（Leonhard Stejneger）に献本されており，自筆のサイン に加えて「Yokohama May 1897」の文字がみられることから推測される (Internet Archive, https://archive.org/にて閲覧, 資料番号：39088002711885)。この頃スタイネガーはクリル諸島 で発見された新種のウミバトを記載しており, 学名をスノーに献名してCepphus snowi（現在 はCepphus columbaの亜種とされる）としているので（Stejneger 1897），この二人は交流があっ たことが推測される。なお，スノーが著したいずれの書にもオーストンの名前は登場しないた め, オーストンがどのようにスノーとかかわっていたのかは不明である。スノーとの共同経営 は4年ほどで終わり，1885年には再び「Alan Owston」と独立名義の名前に戻し（立脇 1996f; Table 1), 以後オーストン商会は1915年にオーストンが没するまで維持されることとなる。

オーストンが横浜ヨットクラブの創立理事であったことはよく知られているが，1886年 10 月に横浜ヨットクラブが創立したとされ, その経緯や当時の様子については, オーストン自身 が1909年に残した文章の和訳（オーストン 1982）と，白崎（1988）の『日本ヨット史』によっ て知ることができる（なおこの本ではオーストンが「元治元年 (1864) 年頃に来日し」と書か れているが，これは間違いであると考えられる)。

1888年には兄フランシスが来日し，1891年までオーストン商会に社員として加わっている (立脇 $1996 \mathrm{~g}$; Table 1)。兄フランシスはオーストンが横浜で事業を始め, 成功したことに惹 かれて来日したものといわれている（Meiji Portraits, http://www.meiji-portraits.de/より閲覧）。 1898年以降は居留地50-B 番でF. Owston \& Co. (「エフ・オーストン商会」とすべきであるが, 「オーストン商会」との混乱を避けるため, 以下英語表記とする）として独立して, 主に港湾 で積荷を扱う業務を請け負っていた（立脇 $1996 \mathrm{~m}$ )。のちには通関事務の代行なども行って いたようである。F. Owston \& Co.について知ることができる新聞記事がある。日露戦争の終結 した1905年10月, 横浜で観艦式が開催された。この前日と前々日にオーストン社と銘打った 
広告が東京朝日新聞に掲載されている。曰く「本月廿三日観艦式挙行当日各位のご便宜を計り 弊社所有の小蒸気曳船を以て御案内可仕候間御申込願上候 廿三日午前九時限り切符販売当日 発船場西の橋及港橋際に於て発売す 金一円也 乗船料一人 横濱市山下町五十番 オース卜 ン社」。れは会社の番地が50番となっているので，兄フランシスによるF. Owston \& Co.の出 した広告である。後述するが，兄フランシスの会社は弟が死亡した 1915 年以降も弟の会社を 吸収して継続していくこととなる。1917年6月22日付東京朝日新聞朝刊には「横濱市山下町 四○エフ・オーストン商会」の名義で「小蒸滊船五拾馬力の滊鑵機關及付属品一切（船體を 除く）を売りたし」との広告がある。これはオーストンの死後，使用されなくなった船を売り に出した可能性があるのでオーストン商会のその後を知るうえで興味深い。買い手がついたの かどうかは定かではない。

オーストンは 1895 年にオーストン商会の同番地に「T. M. Laffin」を共同経営者として横浜 メナジェリー商会（Yokohama Menagerie Co.）という会社を併設している（立脇 1996i）。トー マス・メルヴィン・ラフィン（Thomas Melvin Laffin）は1862年生まれの米国人で，白 崎（1988）によると1885年から横浜在住の記録がある。日本に向かう途中船が難破し横浜に流 れ着いて, 居留地42番「コレア商会」（船舶に積み込む食料雑貨を扱う会社だった）の社員と して働き，店主の死後事業を引き継いだ。同番地は後に「ラフィン商会」という洋酒や食料品 を扱う商社となり，さらに後には清涼飲料水（ラムネやソーダ）の製造業も営んでいたとい う。ラフィンはオーストンとはヨットクラブの仲間であったと考えられ，1898年7月4日には 彼の愛艇マリーとオーストンのゴールデンハインド（後述）が台風の中激戦のレースを繰り広 げたと記録されている（オーストン 1982，白崎 1988，なお永澤 1916では「1895年」と記さ れている)。この頃にはすでに同じ番地で共同経営の会社を動かす仲間であったということに なる。

1902年,「G. Charlesworth」という人物がオーストン商会に加わっている（立脇 1996p; Table 1)。当時日本にいたことが知られる同名の人物として, ロンドン出身のジョージ・チャー ルズワース (George Charlesworth) がある。オーストンが1909年に書いたヨットの話にも「故 G. チャルスワース」として登場するので（オーストン 1982），ヨット仲間であったに違いな い。彼は1854年1月 8 日に生まれ，20歳の時に兄弟を連れてイギリスを離れて横浜にたどり着 き, 輸出業を営んでいたという。1903年3月3日に死亡したという記録がある。JDでは 1874 年の「Imperial Government Railways」に「G. Charlesworth」の名前があるので（立脇 1996a）, 来日当初は鉄道関係の仕事にも関わっていたことがあるようだ。兄弟は後にオーストラリアに 移住し，残された彼は日本人女性 Ichi（関東大震災にて死去，享年 72 歳とのこと）と結婚して 2 人の息子がいた。その一人が同じ George Charlesworthの名を継承している。JDでの「Charlesworth」の在籍は父の亡くなる前年から 1914年までとなっているため, この George Charlesworth Jr.がオーストン商会にいた人物とうかがわれる。息子のジョージはイギリスに送られて 教育を受けた後，横浜に戻ったという（以上 G. Charlesworthの生没年，家族と来歴については GenForum, http:/genforum.genealogy.com/charlesworth/messages/161.htmlからの引用)。

\section{2)-2. オーストン商会の日本人構成員}

スノーとの共同経営によるオーストン・スノー商会時代の初年となる 1881 年から 1891 年の 
間，オーストンは「Imamura Genzo」という名の日本人を雇用している（立脇 1996d，1996h； Table 1)。交詢社刊，『日本紳士録第一版』(1889) 及び『日本紳士録第二版』（1891）によると， この人物が今村源造という名で「横濱区本町 5丁目 70」に居住していたことがわかる（国立国 会図書館の近代デジタルライブラリー http://kindai.ndl.go.jp/info:ndljp/pid/780090にて閲覧。以 下『日本紳士録』からの引用は同様とする)。このオーストンの最初の日本人助手である今村 については今のところ詳しいことはわかっていないが, この時代オーストン商会の番頭とし て, 日本語通訳や店の実質的な経営に関わっていたと考えられる。1882年には「Osa Masamichi」が加わり（立脇 1996e； Table 1)，この二名の日本人とともに（JDでは途中抜けてい る年がある） 10 年間ほどを歩むこととなる。この「Osa Masamichi」という人物は漢字で長 政道と書くことが日本紳士録第三版（1896）に見て取れる。彼はこののち長 聖道（ちょうせ いどう：JDでの記述は「S. Cho」, 立脇 1996n； Table 1）と名前を変えてオーストン商会の日 本人番頭兼採集人として1910年まで所属することとなる人で, 生まれなど詳しいことは不明 である。彼の自然史における業績については, 後で詳しく解説したい。

1894年以降，オーストン商会で雇用する日本人は増加し（立脇 1996j）, 1895年に最多とな り12名を雇用するようになっている（立脇 1996k；Table 1)。磯野（1988）が記述しているグ アムやカロリン諸島へ採集人を送った時期はまさにその絶頂期で, オーストンが自然史標本収 集を一つの業務として取り入れたのはこの頃とされている。JDでは英語表記の氏名のみが掲 載されているが, 日本紳士録では漢字表記で記されているので, 理解が深まる。たとえば 1895 年の記録として，日本紳士録第三版（1896）では下記の記述がある。

「百七拾九番館 Owston ヨーストン 館主 Alan Owston. アレン, ヨーストン 番頭 長 政道 横濱市尾上町三丁目三十三番地 博物掛 飯塚修 輸入掛 山本普津 横濱市老松町一 丁目十八番地 業務 輸入 金物, 機械, 船具 輸出 麦葍真田, 鈕, 手巾, 博物品, 動物, 海植物」

この年の番頭はすでに紹介したオーストンの2 番目の日本人従業員長 政道である。「博物 掛」として飯塚 修という名があるので，この頃には自然史関係の部門も設置されていたこと がわかる。飯塚は1895年と 1896年に所属していた「A. Iizuka」（立脇 1996k, 19961；Table 1) のことと思われるが，イニシャルが「A.」であることからファーストネームの読みが一致しな い。詳しい人物像は全く不明である。輸入掛として山本普津という名があるが，JDではF. Yamamoto となっている人物だろう（立脇 1996k; Table 1)。日本紳士録第5版 (1898) では山本 はオーストン商会の番頭に昇進し,「山本フリツ」とカタカナ表記の名前になっている。前年 まで番頭だった長 政道の名はなく，「鐵物掛」として長 聖道の名が現れる。「博物掛」とし ては山本コル子ルスという謎の人物が登場し，JDの「C. Yamamoto」（立脇 1996k；Table 1) に一致すると思われる。日本紳士録第7版以降では「山本コール」と名前が短縮されているよ うだ。二人の山本は同じ住所に居住していることから親子兄弟あるいは親戚関係にあることが うかがわれる。フリツをFritz，コル子ルスをCornelus と読み替えると，ドイツ系の名前である ように思えるので, 彼らはハーフだったのかもしれない。そのほかこの時代の紳士録には喜多 幸知, 宮前喜衛, 英龍という名があるが，これらの人物については全く不明である。

1901 年にはオーストン商会に「K. Nagayo」という人物が「Naturalist」の肩書付で加入する （立脇 1996o；Table 1)。これはのちに独立して東京神田に標本商「長與標本店」を開く長與 
鼎のことである（説田・時田 2005）。長與がオーストン商会に在籍していたことは日本鳥学会 （1923）に記されている。この文献では「オーストン氏の死去後獨立して標本業に従事された」 と記録されているが，JDで彼の名前が掲載されているのは1909年までなので，オーストンが 死亡する前にオーストン商会から独立したのかもしれない。長與は鳥類分野にたけた標本商で あったことが説田・時田（2005）にうかがわれるが, Meiji Portraits（http://www.meiji-portraits.de） の「OWSTON Alan」の項目で紹介されている当時のポストカードに, 大型のガラス海綿とそ の横に立つ男性（この人物が長與の可能性がある）の写真があり, 脚注としてこのガラス海綿 は「Nagayo K.」によりもたらされたと記述されているので, 水産物の収集にも力を発揮して いたことがうかがわれる。長與については, 鳥類の論文を書いた内田 (1911), 魚類の論文を 書いた Tanaka (1908) が標本を利用した記録がある。

これ以降オーストン商会で雇用される日本人についてはほとんど何もわかっていない。JD では1893年所属の「Cho Otome」（立脇 1996i； Table 1）と 1899年から 1915年まで所属の「H. Cho」（立脇 1996n； Table 1）という名の「長」姓を持つ人物がもう二名いるが，これらは番 頭の長 聖道との関係をうかがわせる。また 1905 年と 1906 年のJDに名前がある「R. Osada」 （立脇 1996q； Table 1）については後述の自然史標本に関する業績において少しだけ触れる。

ここまではJDに従業員として掲載されている人物を見てきたが，未掲載でありながらオー ストン商会で働いていたとされる人物もあるので文献を紹介しておく。この時代の実業家とし て知られる高島嘉右衛門の紹介で 1896 年に入社したとされる野田正一という人物は当時を振 り返り,オーストンに不当な理由で解雇されたという話が『機械商秘史』に書かれている（佐 藤 1940)。これはオーストンの人柄を知るために重要な証言である。1888年創業の新井清太 郎商店は鳥類剥製や「白サギの㝨毛」といった動物製品のほか, 麦蒠真田などを「居留地・ 百七十九番地のオーストラリア系商館のオーストン商会」に売り込んでいたという逸話が「株 式会社 新井清太郎商店九十年史」に記されている。オーストンは「博物館へ出すジュウシマ ツ，ヤマガラなどをよく買っていた」とのことである（株式会社新井清太郎商店1979）。また 1903 年から 1908 年に在籍した人物として寺岡 直があり, 黒田（1953）に詳しく略歴が記され ている。彼はオーストンから鳥類の標本作成を学んだとされ，1905年には「約 2 か月間奄美大 島に滞在。アマミノクロウサギ約200頭を生捕り, ロンドン動物園に送る」（黒田 1953）とあ るが頭数は本当であろうか。オーストンは前述ラフィンとともに横浜メナジェリー商会という 会社も経営していたことから，生きている動物を輸出する業務にも関わっていた可能性があ る。オーストン商会を退職後, 寺岡は前述の長與や後述する小林桂助の会社に所属していた。 動物学雑誌の記事によると「鳥学会の南洋採集者派遣」とのタイトルで, 日本占領南洋諸島に 海軍省の指示で採集人を送ることになったとのことで, 「同会嘱託員, 元オーストン氏採集者, 寺岡直君出発の筈」，と書かれている（日本動物学会 1915）。寺岡は『毛皮年報』という本を 1923 年に「小林毛皮貿易」（小林桂助の会社と思われる）から出版している。オーストン商会 に在籍せず，採集人として雇用された人物はこれら以外にも多数いるが，自然史標本に関する 部分で紹介したい。

\section{2)-3. 船舶事業の推進}

1905 年頃を境にオーストン商会は224番地に引っ越していることが 1906 年度版JDに見て取 
れる（立脇 1996q; Table 1)。同年の 1905 年 2 月 20 日付東京朝日新聞朝刊の広告として,「英 國イーグル會社製造 スチームゲージ 横濱山下町一七九番 アラン，オーストン商店」が掲 載されていることから (Fig. 1), 引越しはこの日以降のことであっただろう。このスチーム ゲージの広告も関連していると思われるが，この頃からオーストン商会は船舶に関わる業務を 拡大した形跡がある。

1906年からオーストン商会には「W. A. Morris」という人物が加わっている。ウイリアム・ モーリス（William Morris）というこの人物について, オーストンは大日本水産会報に報告した 「改良漁船に就いて」という文章中で「英國に於て數年實地經驗ある船用發動器専門技師モー リス氏を傭聘し居りますれば」と書いている（オーストン 1907）。オーストン自身が著述した 文章は当時の様子を知るうえで貴重であるが，この頃オーストンは英国の専門技師を会社に招 いて漁船の設計などに力を入れていたことが分かる。1911年1月の大日本水産会報にはモーリ スが退会した記事が掲載されているので（大日本水産会 1911）, 大日本水産会の会員であった ことがうかがわれる。この年モーリスはオーストン商会の名簿からも外れているので, 帰国し たのであろうか。

この「改良漁船」と呼ばれているものに関する記事として, 1907年の夏に三崎臨海実験所 に来船した「新式漁船」に関する記録が動物学雑誌にある（日本動物学会 1907）。これによる と「八月五日…横濱のオーストン翁新造の改良漁船に乗じて油壳に入り間もなく清水港を差し て帆走し去る」, 及び「八月九日. 熊吉を船頭としてオーストン丸に乗じて大島遠征の途に上 る」とのことである（なお，オーストンは1893年に Miyahara Kameという女性と二度目の結婚 をし 8 人の子供に恵まれたが, 同記事には 8 月 8 日にオーストンが家族を連れて三崎臨海実験

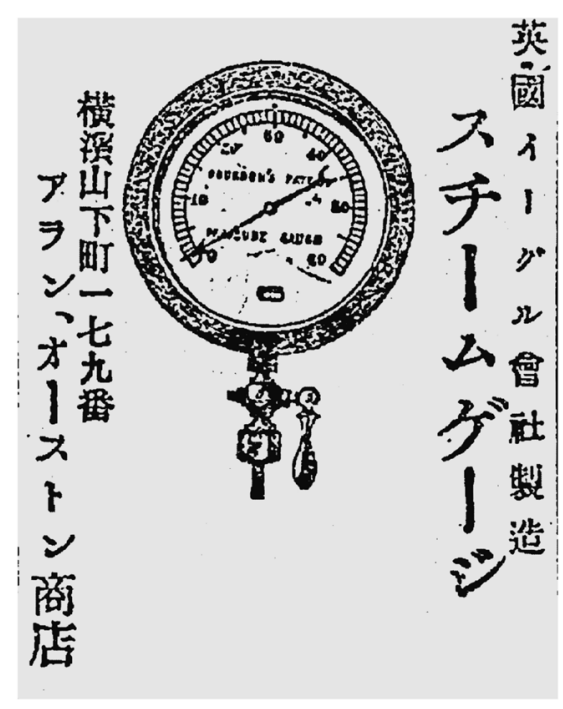

Fig. 1. Advertisement of the natural history dealer 'Alan Owston' appearing in the February 20, 1905, morning edition of the 'Tokyo Asahi Shimbun' newspaper.

図1. 1905 年2月 20 日付東京朝日新聞朝刊に掲載されたオーストン商会の広告. 

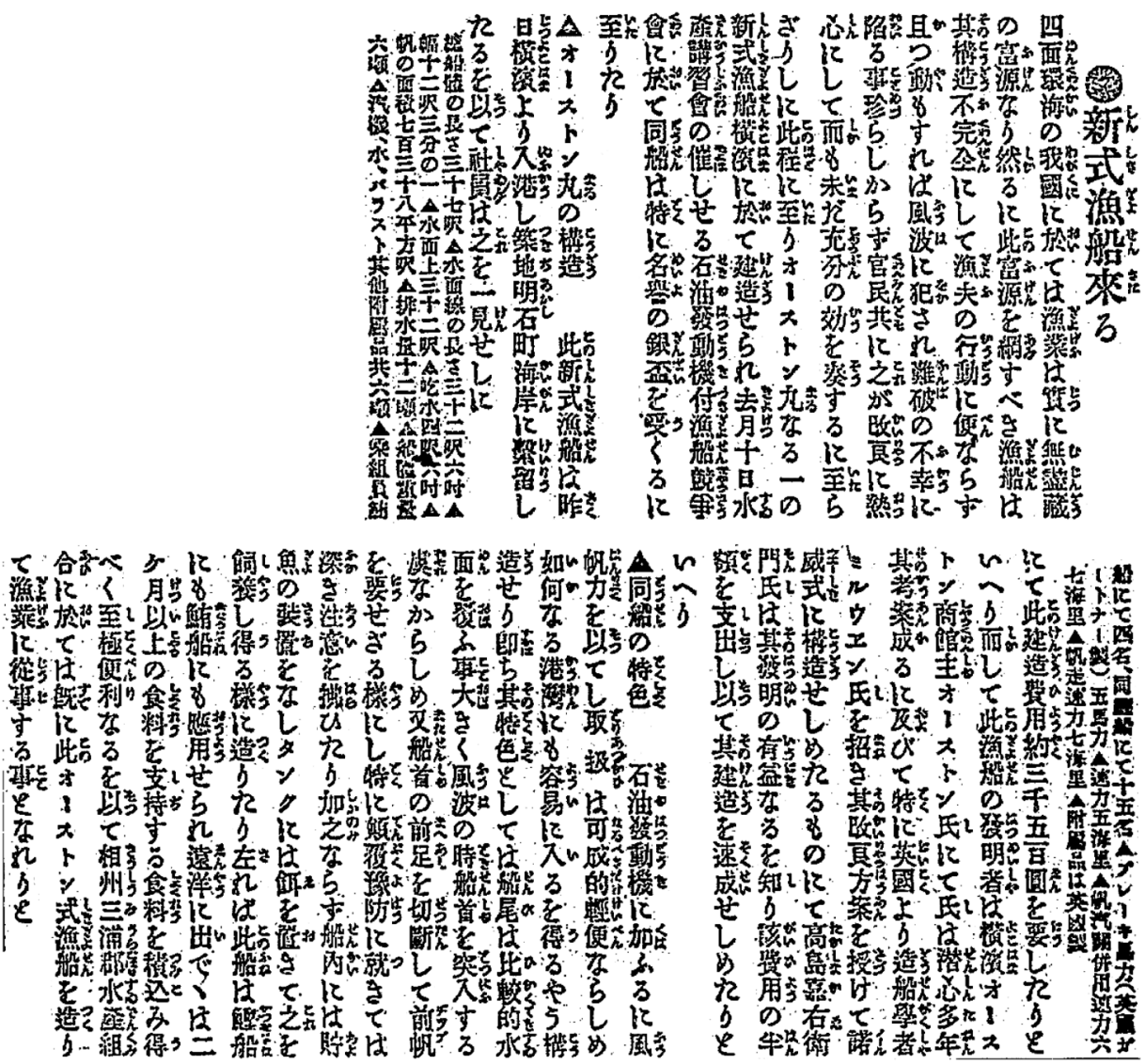

Fig. 2. An article about the new fishing boat 'Owston Maru' appearing in the September 5, 1907, morning edition of the 'Tokyo Asahi Shimbun' newspaper.

図2. 1907 年 9 月 5 日付の東京朝日新聞朝刊に掲載されたオーストン丸に関する新聞記事.

所を来訪した記録がある)。改良漁船が「オーストン丸」と呼ばれていたこと，また伊豆諸島 などにまで調査の足を伸ばしていた様子が見て取れる。またこれに対応するように1907年9月 5 日付の東京朝日新聞朝刊には「新式漁船來る」との記事が掲載されている（Fig. 2)。ここで も「オーストン丸」として紹介され, 費用は当時の約 3,500 円を要し, 半額は高島嘉右衛門が 負担したこと, 英国から「ミルウエン氏」という人を招聘して開発したこと, すでに三浦郡水 産組合がこの漁船を造って漁業に従事していることなどが記されている。

他にもオーストンの執筆した文章として，1909年の大日本水産会報に掲載された「漁船研 究會の提案に答ふ」（オーストン 1909a), 及び同年の大日本水産会報318号に掲載された「佛 國の鰛漁業と發動機漁船」（オーストン 1909b）がある。以上のように1900年代の後半はオー ストンにとって漁船改良に力を入れた時期であったことがわかる。オーストンの死後書かれた 掲載日及び掲載紙不明の新聞記事（鈴木一義氏提供資料）にも「今日，六千隻を超ゆるといは れる發動機漁船の建造を, 日本で最初に計畫したのは, 實に, アラン・オーストン氏なのであ 
ります」と書かれたものがあり, 真偽のほどは定かではないが, オーストンの貢献が見て取れ る。1910年には大日本水産会報に四分の一ページの大きな広告を掲載しており。「登録商標 三六八六一號 GARDNER-OWSTON ガードナー船舶用石油發動機 最も信賴すべき最も經 濟的なる機械にして價格は同種の他のものに比較して低廉なり 日本一手代理 横濱市山下町 二百二十四番 アラン，オーストン」とある。また翌年の同雑誌には 1 ページの「船舶用發動 機販賣」の広告を掲載している（Fig. 3)。時代は然料が石炭から石油に移り変わる頃，これを 機に新型の船舶を紹介し，販売を促進する狙いがあったのではなからうか。

\section{2)-4. オーストン死後の会社動向}

これ以降オーストン商会の動向を示すような資料は見つけられていない。オーストンは 1915年11月30日に横浜で死去した。死因はよくわかっていないが，この時期オーストン商会 から鳥類標本を購入してオーストンウミツバメCymochorea owstoni（現在はOceanodroma tristramiのシノニムだが, 和名は維持されている）などの記載を行った Mathews \& Iredale (1915)

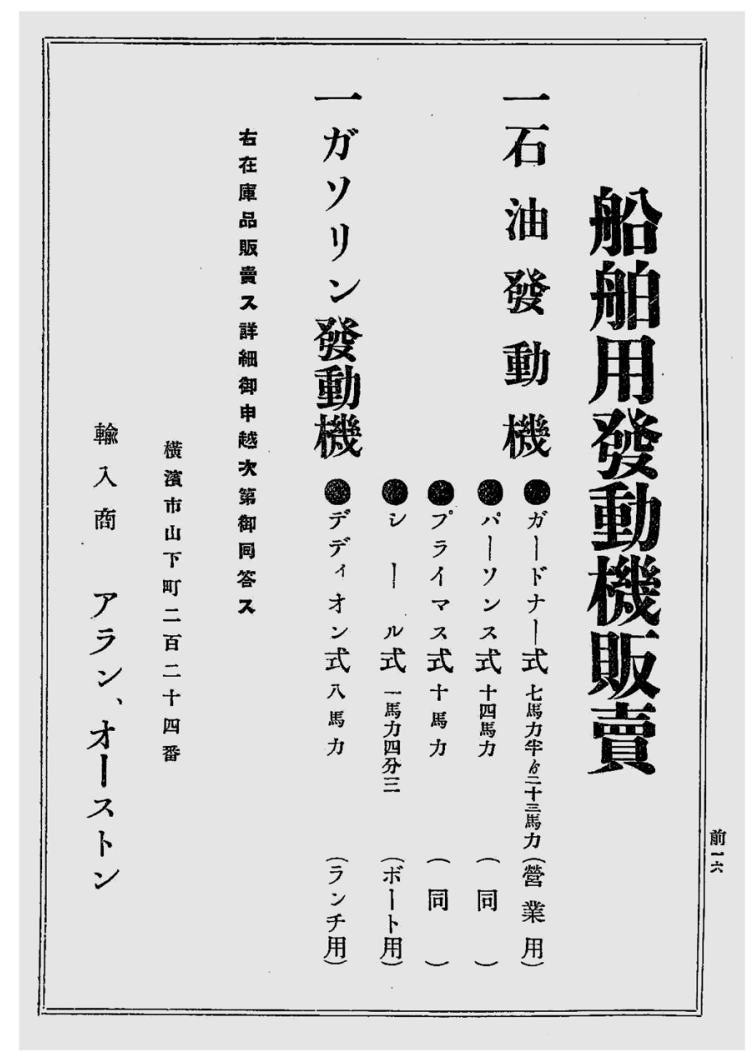

Fig. 3. Advertisement of the natural history dealer 'Alan Owston' appearing in the Journal of the Fisheries Society of Japan in 1911.

図3. 1911 年の大日本水産会報に掲載されたオーストン商会の広告. 
によると，「2回目の小さいロットが届いたが，その後連絡が途絶えている」とのことなので， この文章が揭載された 1915 年7月以前にオーストンは病に伏せていた可能性もある。オースト ンの死後, 残された家族はしばらく横浜の居住地で生活していた記録がJDに見られるが, 1923 年に関東地方を襲った大震災ののち，カナダへと移住したらしい。兄フランシスはオー ストン商会の事業を吸収して，やはり関東大震災まで横浜でF. Owston \& Co. を経営していた ようだが，1918年8月16日の東京朝日新聞によると「チャイナ號坐洲す」という記事にシナ 郵船株式会社のチャイナ号という船が座礁し，「オーストン商会支配人ハッチンソン」氏が人 夫を率いて救出した話があり，この時兄フランシスが会社でどのような立場にあったのかはよ くわからない。その後も社名はJDの1940年まで見られ, 社員として「C. Heseltine」,「T. Yamaki」といった人物が確認できる。1924年 8 月 25 日の朝日新聞朝刊には, 「ヨーストン商會支 配人英國人クロード・ヘセルタイン氏と同キャプテン・イー・ロスタス氏」という人物が関東 大震災で猛火を逃れる民衆 100 人余りを二隻の船で救助したという話があるので, 「C. Heseltine」はクロード・ヘセルタイン (Claude Heseltine) であろう。この新聞記事に登場する「キャ プテン・イー・ロスタス氏」はユージン・ロフタス（Eugene Loftus）という名で, 少なくとも 1932年まではF. Owston \& Co.に勤めていたことが, 国立公文書館の資料（JACAR（アジア歴 史資料センター）Ref. C05021995600, 公文備考昭和 7年 D 外事 巻 1 の (防衛省防衛研究所)) からわかる。これら両氏は関東大震災以降も会社を兄フランシスから任されていたのか, F. Owston \& Co.を経営していたようだ。彼らがいつまで横浜に居住していたのかについてはまだ わかっていない。

\section{3) オーストンと自然史標本}

\section{3)-1. 自然史への目覚め}

オーストンはナチュラリストとして我々によくしられる人物であるが，その萌芽は彼がオー ストン商会を立ち上げた初期の 1882年の文献に見ることができる。Blakiston \& Pryer (1880) は日本産鳥類のチェックリストとしてTransaction of the Asiatic Society of Japanに「Catalogue of the birds of Japan」を掲載した。さらにその 2 年後までに得られた情報を追加して「Birds of Japan」を同雑誌に掲載しているが (Blakiston \& Pryer 1882), この間にオーストンから得た標本 に関する情報が 15 種ほどについて述べられている。 Blakiston \& Pryer（1880）にオーストンに 関する記述が全くないことから考えて, この2つの論文が掲載される間に二人の著者とオース トンの間で交流が深められ，鳥類に関する情報交換が始まったと推測される。北海道大学北方 生物圈フィールド科学センター植物園 (2002) がまとめたブラキストンの鳥類標本目録にも オーストンやスノーが提供した標本が確認できる。

また，スミソニアン国立自然史博物館から依頼を受けたペレ・ルイス・ジューイ（Pierre Louis Jouy）は1882年に自然史標本収集のために来日し, 各地を旅行した。ジューイに関して は河合（2012）に詳述されているのでここでは詳しく述べないが，この調査の報告として同館 の紀要に「Ornithological Notes on Collections made in Japan from June to December, 1882」が掲載 されている(Jouy 1884)。この論文の冒頭でオーストンと共同で働いたこと，採集に便宜を 図ってもらったことが書かれている。ほかにブラキストン，スミス，プライアに対する謝辞も あるのだが，オーストンが一番に取り上げられて世話になった経緯が示されているところに， 
貢献度の高さがうかがえる。また，スミソニアン協会年報の 1883 年の記録にも，ジューイが 来日した際に「Owston Snow \& Co.」が協力し, その標本が寄贈されたことが書かれてい る（Baird 1885）。具体的にどのようなかかわりがあったのかは不明であるが，少なくともスミ ソニアン国立自然史博物館のデータベースには，1883年4月に「Kawasaki River」で「Owston; Jouy, P. L.」が採集したとされるヤマセミMegaceryle lugubrisの標本が2点登録されている （http://collections.nmnh.si.edu/search/birds/にて閲覧，標本写真とラベルはWeintraub（1998）でも 確認できる)。このことからオーストンが採集した標本がジューイに譲り渡されたことを確認 できる。初めて来日したジューイにとって, 日本の立関たる横浜で外国人貿易商として事業を 営んでいたオーストンは頼りになったに違いない。

これらのことから，すでに1880年代にはスノーの毛皮輸出や収集標本の海外販売，また海 外からの採集人への協力といった面でオーストンは自然史研究への貢献をスタートしていた可 能性が高い。英国時代の彼の自然史キャリアは全く不明だが，父フランシスが故郷のドリフ フィールド (Driffield) 時代にツグミの一種についての観察を記録した報文があることか ら (Owston 1844), オーストンも鳥類への関心が高かったことが推測される。来日した頃には すでに自然史に対する関心を持っていたのではないだろうか。

オーストン自身が自然史関連の分野で記したものはあまりないようだが，知られているもの としては，1897年12月26日に小田原城付近でアマツバメApus pacificus の飛翔を観察した報告 があるのと（オーストン 1898），その続報と思われる英文の記事 (Owston 1899) がある。い ずれも自然史標本ディーラーとしてすでに活躍期にあるものである。

\section{3)-2. 事業としての自然史標本収集}

オーストンが自然史標本を提供した記録は上記Blakiston \& Pryer（1882）の記録やスミソニ アン国立自然史博物館に登録されている1883年の標本が最も初期のものと考えられるが，こ れらがオーストン商会の事業として販売されたものかどうかは明確ではない。一方, ジェラル ド・E・H・バレットハミルトン（Gerald Edwin Hamilton Barrett-Hamilton）はユキウサギLepus timidus の亜種分類に関する論文で, オーストンから購入されたと明記されている英国自然史 博物館所蔵標本（BM84.4.15.2）をタイプ標本としてエゾユキウサギL. t. ainuを記載してい る（Barrett-Hamilton 1900）。英国自然史博物館の標本番号は西暦の下二桁を頭として付される ことから，この標本が 1884 年に登録，それ以前にオーストンから購入されたことは間違いな からう。これらの散発的な標本情報は, オーストンが個人的あるいは商会の業務として販売し ていたのかが明確ではない。

オーストン商会が自然史標本を扱う会社として明確に位置付けられた記録は磯野（1988）で は1895年頃と記されているが，これはこの年からJDに「Import and Export Merchant and Naturalist」と業務内容が記されているためである（立脇 1996j）。しかしこれをさかのぼる数年前 の 1890 年 12 月 12 日付で英国のトリング市にあるロスチャイルド動物学博物館のキュレーター であるアルフレッド・ミナール（Alfred Minall）に送られた請求書が, 英国自然史博物館の アーカイブに残されている (川田未発表)。その内容は鳥類標本 144 点を 49 ポンド 9 シリング で販売したもので, これほどの標本を一度に送付するということは個人業務としては考えがた いように思われる。その後オーストンはたびたびトリングの博物館宛に鳥類標本を主とするコ 
レクションを送付し, 標本はライオネル・ウォルター・ロスチャイルド (Lionel Walter Rothschild）やそのキュレーターのエルンスト・ハータート（Ernst Hartert）によって研究されること となる。このことからオーストンが事業として自然史標本を扱い始めた時期には再考が必要で ある。後述するように，少なくとも1894年3月には標本買入の社名入り新聞広告を掲載してい るので，磯野（1988）の指摘する年よりは早まると考えられる。

標本収集のための国内調査もこの頃から盛んにおこなわれるようになる。籾山（1930）によ ると「1892年から 1893 年頃オーストンが小笠原に採集人を送った」と記されており，例えば それを示す証拠標本として, 山階鳥類研究所には 1893 年小笠原採集のアカガシラカラスバト Columba janthina nitens やカツオドリ Sula leucogasterが存在する。調査済みの資料からオースト ン本人が小笠原や他の地域へ採集に赴いた確実な証拠はなく，おそらくこの頃から遠隔地に日 本人採集人を派遣して，自然史標本の収集を行っていたのだろう。

この頃は東京帝国大学教授の飯島 魁との交流が盛んになった時期である。飯島（1893）の 「やまからノ新種二就テ」は1893年10月 21 日と 30 日に三宅島で採集された標本に基づくオー ストンヤマガラ Parus owstoni（現在はヤマガラ Poecile varius の亜種）の記載論文である。飯島 は「1893年3月に標本を調べさせてくれた」とのことで，その後一点はタイプ標本として東京 帝国大学に，もう一つはオーストン所有となっている。この論文中で飯島はオーストンを名指 しではなく「that gentleman」と呼んでいることに注目したい。そののちには「my friend」と いった呼称になっていることを考えると, この標本提供が最初のことであったことを連想させ る。その後飯島は小笠原産カラスバト（飯島 1894a）や「いはみせきれい」（飯島 1894b）に 関する論文においてたびたびオーストン由来標本の報告をしている。1894年4月7日にはオー ストンが三崎臨海実験所を訪問した記録があり（日本動物学会 1894）, 後述する通り水産物の 調査にも参加したようだ。以後オーストンはたびたび三崎を訪れるようになる。

オーストンと飯島の出会いは少し年をさかのぼって1891年あたりであったと考えられる。 この年の動物学雑誌には三崎臨海実験所において東京帝国大学工科大学（以下工科大学とす る）教授の「ウェスト」という人物の操縦するヨット「大名丸」で学生が採集を行った話が記 録されている（日本動物学会 1891a, b）。このウェスト（Charles D. West；白崎（1988）ではG. D. ウェストとされている）という人物は, 工科大学でお雇い外国人として教授職にあった人 である。アイルランドで生まれ（磯野（1988）ではイギリス人とされている), ダブリンで学ん だ後イギリスの造船所で設計技師として働いていた。1 882 年に来日して政府雇用の工科大学 教授の地位に就き，1908年に61歳で亡くなるまでその職にいた（白崎 1988）。日本動物学 会（1891a）の記述によれば，1890年にはすでに三崎を訪れて，採集の手伝いをしていたよう だ。また, 同じく工科大学の教師だったジョン・ミルン（John Milne）を伴って, 二人が三崎 臨海実験所を訪問して，「初の灯火採集」を行った様子を磯野（1988）が紹介している。

さて，1891年の 4 月 25 日から 26 日に行われた大日本水産会第九回大集会の 26 日午後 2 時か ら行われた演説会において, オーストン（本會記事では「帆船クラブ名譽書記ウヨストン」と なっている), ウェスト, 飯島及び東京帝国大学の松原新之助が演者として登壇している（大 日本水産会 1891a)。オーストンと飯島の出会いはこの時であったようで，ウェストはすでに 三崎で海産物収集を手伝っていたことから，ウェストが飯島にオーストンを紹介したのかもし れない。なお大日本水産会大集会でのオーストンの発表は「日本二適スル漁船ノ説」と題し, 
大日本水産会誌 111 号に「漁船卜快船卜ノ關係」というタイトルで内容が掲載されている （オーストン 1891）。ここでの署名は「横濱帆船クラブ名譽書記 オーストン」とあり，横浜 ヨットクラブの代表として登壇したようである。オーストン自身が書いたものとしては知られ る限り最も古いもので，重要な記録である。

こうしてオーストンは各地に採集人を送って主に鳥類と昆虫類を収集し，それらを英国の口 スチャイルドや東京帝国大学へ販売あるいは寄贈するようになった。磯野（1988）が記述して いるように, 1893年にはグアム, カロリン諸島といった南洋へと Furusawa Genji と Okazaki Riukichi という二名の従業員を送った。このコレクションは英国に送られてロスチャイルドに よってグアムクイナHypotaenidia owstoni（現在はRallus owstoni）などの記載が行われることと なった (Rothschild 1895)。

オーストンは社員を地方に送り込んだだけでなく，日本各地で採集人を育成して標本収集も 行っていた。1894年3月27日付東京朝日新聞にはオーストン商会の「鳥ノ玉子, 巣買入」と いう広告が掲載されている（Fig. 4)。これによると標本製作に必要な道具を提供する旨, 隕 石・鳥獣・貝・海藻・培柱（「塩柱」と別の広告には書かれている）といった自然物を広く買 い入れようとしていることがわかる。オーストンが地方で雇用した人物の一人, 高山鼎二につ いて記述した『鳥学を支えた岳人』には, 当時オーストンから譲り受けた鳥類卵の標本作成の 道具が写真入りで紹介されている（林 1991）。高山は1897年に横浜のオーストンを訪ねたと いう。おそらく新聞記事を見てのことではないだろうか。なお新聞広告は読売新聞（1895年 4

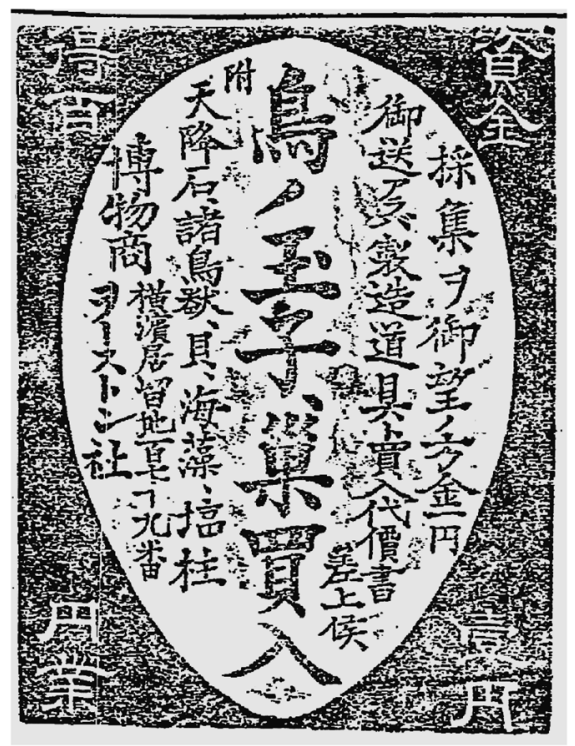

Fig. 4. Advertisement of the natural history dealer 'Alan Owston' appearing in the March 27, 1894 edition of the 'Tokyo Asahi Shimbun' newspaper. The surrounding eight ornamental letters, meaning '1 yen fund to be 100 yen profit', are fascinating.

図4. 1894年3月 27 日付東京朝日新聞に掲載されたオーストン商会の広告. 周囲の「資金壹円得百円 業」というふれこみが面白い。 


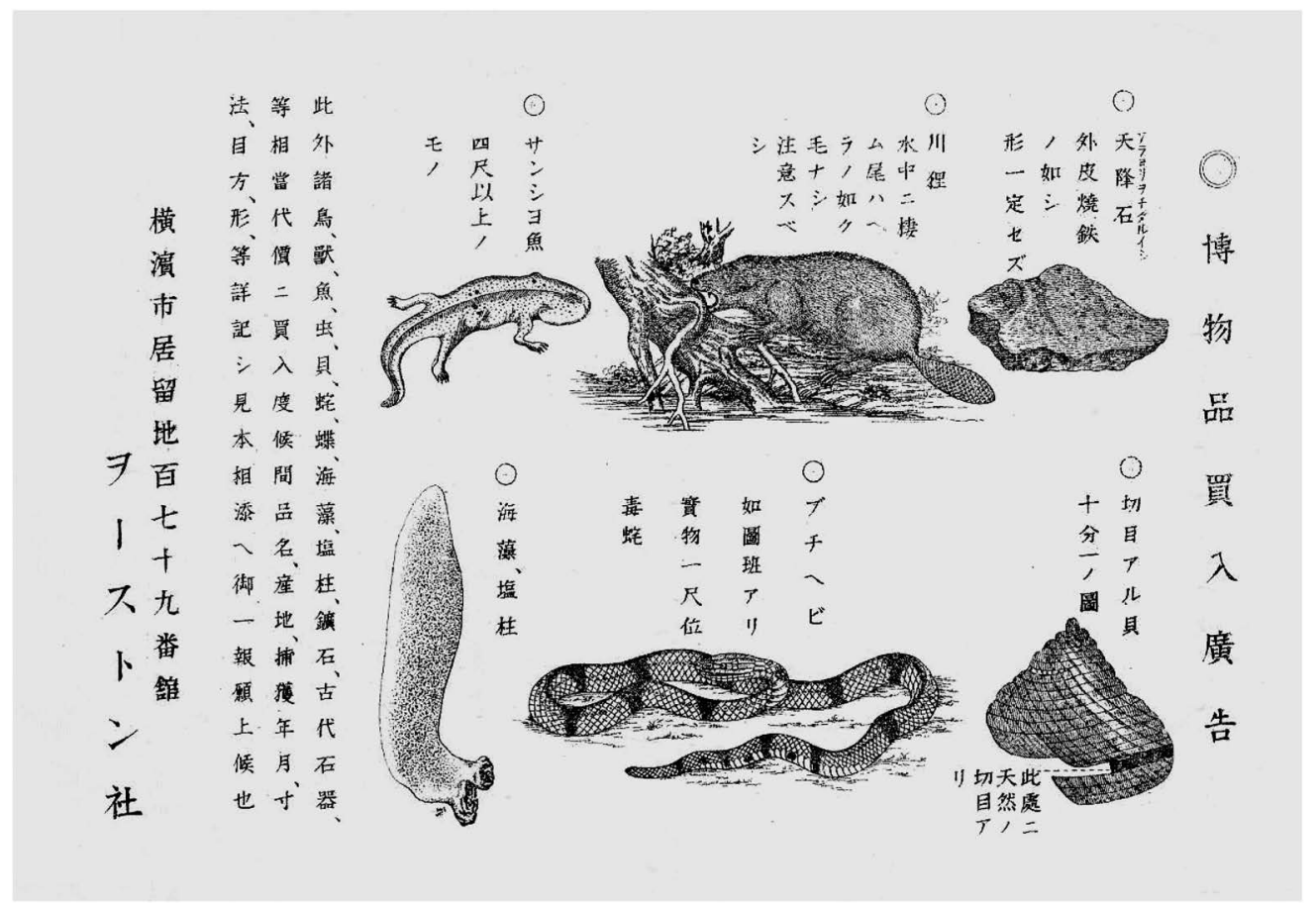

Fig. 5. Flier of the natural history dealer 'Alan Owston', thought to be printed around 1900. It can be seen that several materials, e.g. meteorites, stone tools and seaweeds, other than animal specimens, e.g. slit shells, beavers, poisonous snakes and salamanders, are also available.

図5. 1900 年前後のものと思われるオーストン商会のチラシ. 隕石, 切目アル貝 (オキナエビス), 川狸 (ビーバー), ブチへビ (毒蛇とのことなので, おそらく琉球のヒャンや八イであろうか), サンショ魚（四尺以上なのでオオサンショウウオであろう）, 海藻, 塩柱とある，そのほか石 器なども扱っていたことが分かる.

月 8 日朝刊）にも見られ，また販売品を印刷した紙片を配布していたようだ（鈴木和義氏収集 資料；Fig. 5)。動物のみならず，隕石まで販売していたのには驚かされるが，一例として1891 年12月に米国のヘンリー・ワード（Henry Ward）という人物に岩手県で収集された隕石が送ら れ，記載されている（Ward 1892）。この話は佐藤（1997）により記述されているのだが，少々 補足したい。ワードは地学者でロチェスター大学の教授職にあった人物で, 後に自然史標本を 販売する会社Ward's Natural Scienceを開いた。明治時代に当時の帝室博物館へオーストラリア 産ジュゴン Dugong dugonの全身骨格標本を販売したこともあり（国立科学博物館 1998）, こ の標本は現在でも国立科学博物館に保存されている。このように日本にも標本を販売していた 経緯があったことから，オーストンはワードのことを知り隕石を送ったのではないか。もしか したら自然史標本の事業についてアドバイスなども受けていたのかもしれない。

\section{3)-3. 水産物の調査}

オーストンは 1895 年夏に自作のヨット「ゴールデンハインド」を製作，これによって水産 
物の収集が促進されていった。たとえば1896年7月11日に飯島と同大学教授箕作佳吉がゴー ルデンハインドに乗って横浜から三崎へと来航し, 調査を行った記録（日本動物学会 1896, 渡部 1896）があり，「奇妙なる動物」として報告されたクシクラゲCtenophoraを採集している （西川 1896）。また同年10月15日にも飯島がゴールデンハインドで三崎に入港したという記事 がある。ゴールデンハインドは1903年沈没したとのことだが(磯野 1988), 日本動物学 会 (1903) によると同年8月にゴールデンハインド号で遠洋に採集に行った逸話が記録されて おり，13日午後「ゴルデン，八インド横浜へ馳せ帰る」とあるので，この後年内にゴールデ ンハインドは沈没したものと思われる。オーストン（1982）本人の言によれば「ある嵐の晚, 富津岬周辺で行方不明になってしまった。非常に激しい嵐で, 沖に出ていた多くの漁師たち も, 気の毒に千葉の海岸に何十もの死体となって打ち上げられた」とのことである。というこ とは，オーストンは乗船していなかったのだろうか。

飯島はこの頃には鳥類研究から離れつつあり, ガラス海綿などの水産物に強く関心を持って いたようだ。それに応じてというわけではなかろうが，オーストンは相模湾での調査をかなり バックアップしていたようで, オーストンから提供してもらったガラス海綿に関する論文で オーストンホッスガイ Hyalonema owstoni な゙をを記載している（Ijima 1894）。また箕作も同様に 水産物の研究を行っていたため, この三人が行動を共にすることはさぞ多かったことだろう。

オーストンが箕作にも研究材料を提供していたことは，ちょうどこの頃有名なミックリザメ が記載されていることからも見て取れる。この深海性のサメはオーストンが漁師から入手した 個体が初の記録となる。この標本を箕作に提供し，箕作はそれを1897年にカリフォルニアで 行われたアザラシ類の国際会議（International Fur Seal Conference）に持参して, 記載者である デビッド・スター・ジョーダン（David Starr Jordan）に知られるところとなる。ジョーダンは この標本を精査し, ミックリザメを新属新種としてMitsukurina owstoni の学名を与えた。属名 は箕作に捧げたもので, 種小名は箕作の頼みでオーストンに献名したとのことである (Jordan 1898)。ここで注意したいのはこの論文中でオーストンのファーストネームを「Allen」と 間違えていることで，おそらくジョーダンはこの時にはまだ直接オーストンに面識がなかった ことがうかがえる。オーストンは 1903 年頃には様々なサイズのミツクリザメを複数個体所有 していたことがスミソニアン自然史博物館のバートン・A・ビーン（Barton A. Bean）によって 記録されている（Bean 1905）。ビーンによると，日本を訪問した知人がオーストン商会に「い いシリーズの本種が4から10フィートのものまでそろっていた」という。これらの個体は欧米 の博物館に送られることになったようである。

1897 年 2 月 15 日に飯島, 箕作及び波江元吉と気象台の技師和田の 4 名は横須賀を訪問してい る（波江 1897）。目的はこの時停泊中だった米国の調査船アルバトロス号を見に行くことだっ た。同艦でオットセイ類の調査員として来日していたスタイネガーの誘いだったという。途中 オーストンもまたスタイネガーの誘いを受けていたとのことで同行し，合計5名でアルバトロ ス号を訪問した。スタイネガーはスミソニアン国立自然史博物館の研究者で, 初期に鳥類を, 後期には両生類, 爬虫類を研究した。前掲のように, オーストンの元共同経営者であったス ノーとスタイネガーもこの頃には関係を持っていたことやジューイの来日の件によるのだろう か, すでにオーストンはスミソニアン国立自然史博物館との交流があったようで, 後にスタイ ネガーに送られた標本によって両生類, 爬虫類などの記載が行われることとなる。アルバトロ 
ス号はその後1900年に横浜へ入港し, ジョーダンやアレクサンダー・アガシ (Alexander Agassiz）といった研究者が東京帝国大学で講義したり（日本動物学会 1900a, b), 三崎臨海実験所 を訪問したりしている。また東京帝国大学の学生を連れてドレッジ調査なども行ったと記録さ れている。この折に横浜か三崎でオーストンとの交流があったことは疑うべくもない。アガシ の来日時は東京動物学会と東京地学協会が協議して, 3月9日に東京帝国大学に招いたという （日本動物学会 1900a, 東京地学協会 1900)。この記事が掲載された地学雑誌 12 号 135 巻には, 参加者の記念写真が添付されている（Fig. 6)。この写真で前列中央に座するのがアガシで, 向 かって左に飯島右に榎本武揚（当時の東京地学協会副会長）という重鎮が控えている。また榎 本から右に一人おいて箕作が座り，その右でステッキを抱えて座るのがオーストンである。

これ以降，オーストンは米国の研究者に盛んに三浦半島などで採集された魚類をはじめとす る水産標本を販売するようになったようだ。それらの多くはジョーダンによって調べられ， オーストンクサウオ Trismegistus owstoni（現在の学名はLiparis owstoni）などの新種記載がなさ れた (Jordan \& Snyder 1904)。Jordan \& Starks（1907）は同様にオーストン由来の魚類コレク ションをまとめたものであるが, ここではオーストン以外に「Yonekichi Koneyama, a natural

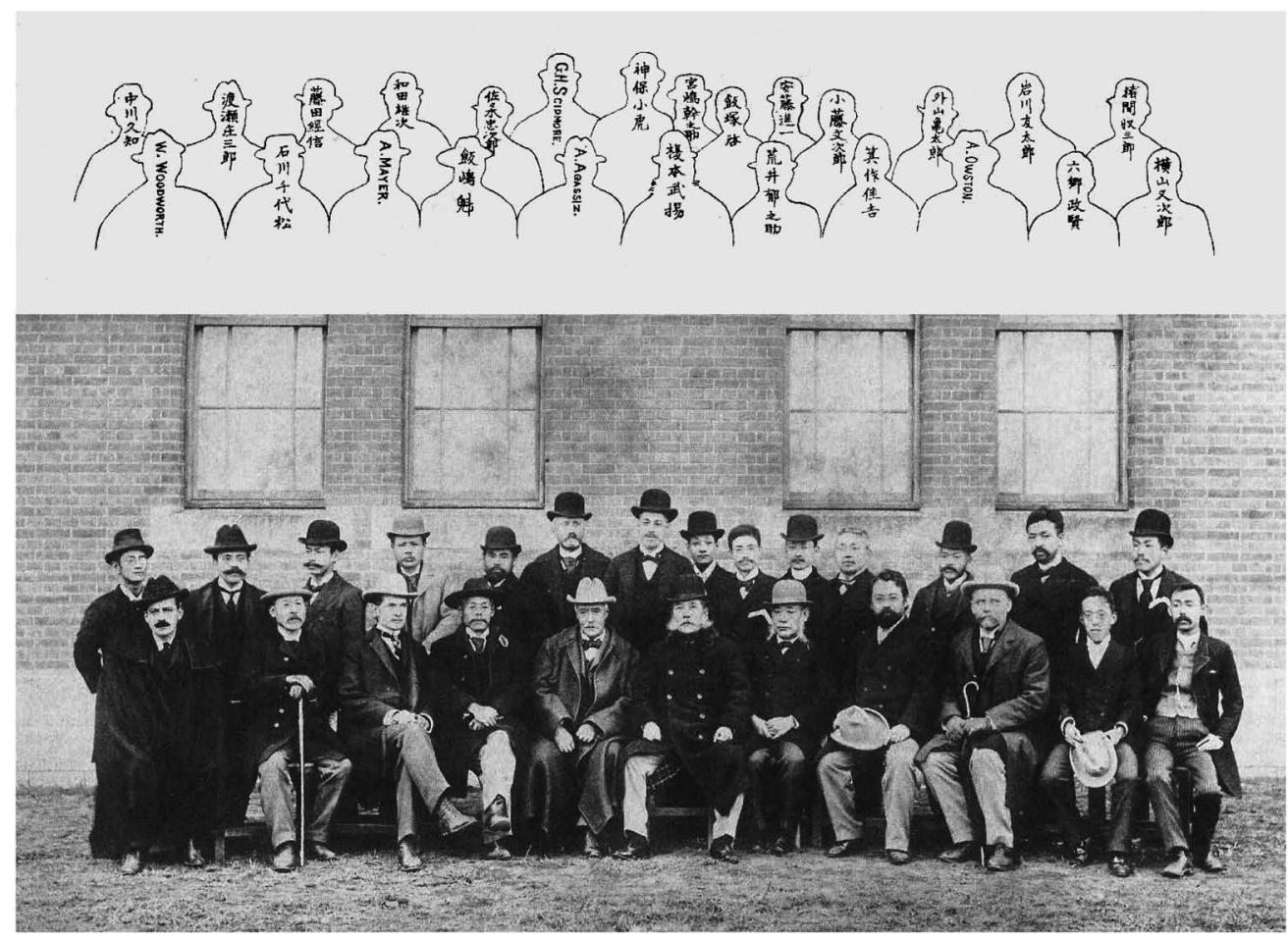

Fig. 6. Group photography at lecture by Dr. Alexander Agassiz at Tokyo Imperial University, dated March 9, 1900. The gentleman with hat and cane sitting the third from the right side of the front row is Alan Owston. Reprinted from the Journal of Geology, Vol. 12 No. 4.

図6. 1900年3月9日に帝国大学で行われたアレクサンダー・アガシの講演会における集合写真. 前 列右から三番目がオーストンである. 地学雑誌 12 巻 4 号より転載. 
history dealer in Tokyo」（米山米吉のことであろう）からの標本も使用したと記述されており， オーストン商会以外にも自然史標本ディーラーがあったことを示している。そのほかにも魚類 の一部はハーバード大学の比較動物学博物館へ送られたようで, 同館のサミュエル・ガーマ ン（Samuel Garman）によるオーストンツノザメCentroscymnus owstonii といった種にもオースト ンの名前が捧げられている（Garman 1906）。

また東京帝国大学へも多くの標本を寄贈していたようで，1904年 8 月 4 日付の東京朝日新聞 によると，「英國人へ銀杯下賜」という記事が掲載されている（Fig. 7)。これを引用すると「横 濱山下町在留英國人アラン, オーストン氏は去三十三年一月東京帝國大學理科大學へ動物學参 考用として本邦編纂動物四百點並に沖繩諸島産動物五十點を寄附したる廉に依り其賞として銀 杯一個を下賜せらる」とある。この頃には東京帝国大学の飯島, 箕作といった教授への援助を 惜しまなかったようで, 標本は飯島, 箕作の下で研究を行っていた田中茂穂など学生による調 査が行われている。田中が記載したものの中にはギンザメの新種Chimaera owstoniから始まり (Tanaka 1905, 田中 1905 にも解説記事), この種の和名は後にオーストンギンザメとされた (田中 1908)。新属Owstonia として記載されたソコアマダイO. totomiensis も田中によるもの で (Tanaka 1908), オーストンへの謝意がうかがえる。後者の論文ではスズキベラ属の一種 Anampses nagayoi という種も記載されているが, この名の由来として「Mr. Owston's assistant」 と記されているので, 従業員の一人長與 鼎に献名されていることが明らかである。標本は 1903 年に鹿児島県で採集されていることから, 長與が派遣された可能性がある。新種記載と は別の文献として田中（1910）でもオーストン由来の標本が利用されている。

そのほか相模湾をはじめとする日本近海で採集された水産物は動物群ごとに世界各地の研究

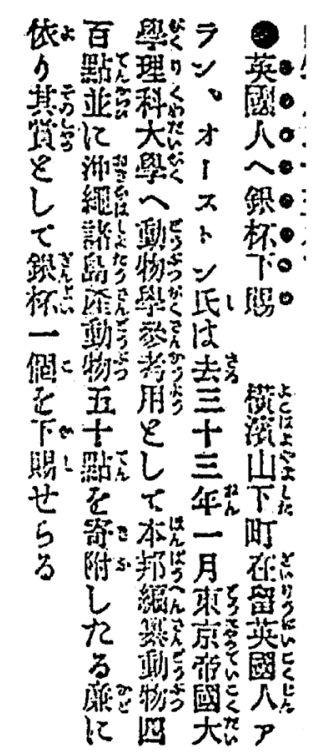

Fig. 7. An article published in the August 4, 1904 edition of the 'Tokyo Asahi Shimbun' newspaper, describing the awarding of a silver cup to Owston.

図7. 1904年 8 月 4 日付東京朝日新聞に掲載されたオーストンが銀杯を下賜されたとの新聞記事. 
者により調査が行われている。棘皮動物に関しては 153 点, 40 種がハーバード大学の比較動物 学博物館により購入され, ハバート・ライマン・クラーク (Hubert Lyman Clark) が8種を新種 記載している（Clark 1908b）。棘皮動物の一部はスミソニアン国立自然史博物館へ送られたよ うで, 米国水産局オースチン・クラーク（Austin Hobart Clark）がオーストン由来のウミシダ 類 (Comatulida) 70点余りの記載を行っている (Clark 1908a)。ウ二は英国自然史博物館に送ら れフランシス・ベル (Francis Jeffrey Bell) の手に渡ったようだが, 専門外だったのか 1902年の 秋にデンマーク，コペンハーゲンのテオドア・モーテンセン（Theodor Jensen Mortensen）に転 送され調べられた。Mortensen（1904）はオーストンフクロウニAraeosoma owstoni の記載を行っ たが，その中でオーストンの名前を「Owsten」とまちがえている。学名は収集者の名を，と いうベルの希望により「Araeosoma owsteni」とされたが, 同雑誌同巻に「Araeosoma owstoni」 にするという修正文が掲載されている。彼は1914年に三崎臨海実験所を訪問しているが，そ の折にオーストンに会うことができただろうか。棘皮動物に関しては後に東京帝国大学の後藤 清太郎によっても整理され，オーストンの東京帝国大学寄贈標本を基にモノグラフが作成され ている（Goto 1914）。さらにイタリア，ミラノの博物館に送られた十脚類をブルーノ・パリ シ（Bruno Parisi）が新種記載したもの（Parisi 1917）にオーストンが採集した記述や，1906年に Harold Heath という人物に送られたヒモムシの標本6点をE. A. Foshayが調べたという記録（駒 井 1919), 英国自然史博物館に送られたガラス海綿のコレクション（Günther 1906）などが見 つかったが，まだかなりの記録が埋もれているに違いない。

\section{3)-4. 採集人, 勝間田（石田）善作}

1899年, オーストンが琉球列島に採集人を送ったことがいくつかの現存する標本と文献情 報からわかる。この年に収集された標本として, たとえば東京大学総合博物館の無脊椎動物標 本データベースにはオーストン氏寄贈として多数の琉球産カ二類標本が確認できる（http:// umdb.um.u-tokyo.ac.jp/fmi/xsl/DDoubutu/invertebrate/result.xsl)。これらの標本は前述した東京朝 日新聞記事（1904年8月 4 日付）にある「英國人へ銀杯下賜」の寄贈標本の一部である可能性 が高い。また, スタイネガーによる「Herpetology of Japan」はスミソニアン国立自然史博物館 の紀要に報告された大著で (Stejneger 1907)，1996年に松井正文によって復刻製本された。こ の中にオーストンから提供された1899年八重山諸島産標本の記述が多数ある。スタイネガー は1905年にもサキシマカナへビ Takydromus dorsalisを記載したが (Stejneger 1905)，このタイ プ標本は石垣島で 1899年4月～6月にかけて採集されたものである。これらも同じ調査旅行で 収集されたものと考えられる。さらに，採集年は示されていないが，Jordan \& Snyder (1901) ではクリミミズアナゴMuraenichtys owstoni をはじめ数種ウナギの類が記載されており，「アラ ン・オーストン氏によって八重山で得られた」とのこと, その他数種がオーストン由来の南西 諸島産標本として挙がっている。

1899年の採集人に関するヒントは以下の文献である。Bangs（1901a）は，オーストンから購 入した琉球列島の鳥類標本のチェックリスト, またBangs（1901b）は琉球列島産の哺乳類標本 を記載しているが，これらが「Zensaku Ishida」という人物によって採集されたものであるこ とが記されている。カグラコウモリHipposideros turpisはこの論文で記載された種である。こ れらの記載を行ったのはオートラム・バングス（Outram Bangs）というアメリカの哺乳類鳥類 
学者でハーバード大学の比較動物学博物館の人である。彼は幼少期から鳥類の採集を行ってい たが, 大学生時代には米国産哺乳類の研究に転じた。ハーバード大学にアシスタントの職を得 た1899年以降, 鳥類研究に戻ったらしい。1901年にハーバード大学で最初に書いた論文が, ちょうどその頃入手した琉球の鳥類と哺乳類に関するものであったという（Peters 1933）。

この Bangs（1901a）に記されている「Zensaku Ishida」について小川（1906）は「千八百九十九 年一月駿河國駿東郡小木原なる石田善作, 横濱の Owston氏の命を受けて琉球群島に航し」と して, 漢字表記で石田善作であることを解説している。この人物はのちに姓を勝間田として中 国海南島へと移住する勝間田（石田）善作のことであるとわかる（川田・安田 2012）。長 沼（1943）によると, 勝間田（石田）は1890年にオーストンに出会い, その鳥類の収集能力を 認められて採集人となり, 1895 年 3 月から岡崎の中根松十郎を伴って琉球調査へ赴く。そして 姓を石田から勝間田へ変えて, 決死の覚悟で1896年7月に海南島の調査に旅立つと描かれてい る。これらの調査はオーストンが英国のロスチャイルドからの依頼で行われたものとされてい る。著者の長沼依山は「昭和十五年三月, 軍の斡旋によって, 海南島へ渡り, 翁がなくなられ る數日前, 圖らずも, 翁やその令息にあひ, その奮闘四十五年の歴史をうかがうこと」によっ て勝間田の伝記をまとめたとされており, 伝記をまとめるに先駆けて1940年発行の「實話讀 物」7月号に勝間田に関する短い伝記を執筆し，ここでは琉球調査行を1894年からとしている （長沼 1940）。類似した記述は1936年9月26日付大阪朝日新聞にも見られ，オーストンとの出 会いについて「明治二十五年三月十七日東京朝日に出た横濱山下町のオーストン商会の「小鳥 の卵を買いたし」の三行欄がめについた」ことからオーストン商会を訪問したとされている。 また1939年3月発行の雑誌「實業の日本」に掲載された記事によると，オーストンから依頼を 受けた「卯之助」という人物が「今から五十年前」に勝間田の故郷を訪れた際に出会ったのが 始まりとされ，また海南島に旅立ったのが 23 歳の時（勝間田は 1874 年 1 月 4 日生まれとのこと なので, 1897年）と記述されている（品川 1939）。このように勝間田とオーストンの活動に 関する年代やその他の詳細は整合性がとれない。これらは約 50 年前の記憶に基づくインタ ビューによるものであると考えられ, 上記 1899 年の琉球調査関連文献の記述や, 勝間田が海 南島で収集しオーストン経由で購入したとされる鳥類標本の年代が 1902 年以降のものである こと（Hartert 1910）を考慮すると，長沼（1943）等が記した年代推移については疑問を呈する ため,これは稿を改めて詳しく解説したい。

ここでは勝間田が海南島で収集してオーストン経由で送られた標本がどのように利用された かについて述べたい。まずすでに述べたように鳥類の大半は英国のロスチャイルドに送られ て, 彼のキュレーターであるハータートが海南島の鳥類についてまとめている（Hartert 1910)。爬虫類, 両生類についてはハーバード大学の比較動物学博物館に送られたようで, 同博物館のトーマス・バーバー（Thomas Barbour）が海南島や台湾からの標本を調査し, 多数 の新種を記載している（Barbour 1908）。特に爬虫綱有鱗目に分類されるトカゲモドキ属 Goniurosaurus の属記載は海南島の五指山にて1906年11月16日に採集されたハイナントカゲモドキ G. hainanensisに基づいており, 注目に值する。時期と場所から見て勝間田の収集品に間違い ないと思われる。哺乳類については1902年12月から 1904年7月までに収集された標本 238 点 がオーストン商会からニューヨークの米国自然史博物館に購入された。同博物館の哺乳類, 鳥 類キュレーターだったジョエル・アサフ・アレン（Joel Asaph Allen）によってまとめられた 
チェックリストによると31種に分類されている（Allen 1906）。特記すべきこととして, 留歯 目リス科のホオジロシマリス属Tamiops が新属として記載されている。またセンザンコウの一 種 Manis pusilla（現在はミミセンザンコウM. pentadactylaの亜種）などの記載がある。さらに 1905 年頃採集の標本も同博物館により購入され，Allen（1909b）が調査し，いくつかの新種, 新亜種が記載されている。また英国自然史博物館に所蔵されている八イナンモグラ Mogera hainanaのタイプ標本とそのシリーズはやはりこの時代に海南島から得られたもので, オース トンから購入されたものである（Thomas 1910）。同時代の勝間田採集と思われるコレクション は, 山階鳥類研究所, 森林総合研究所でも見つかっており, 採集品がオーストンにより選別さ れて国内外の研究機関に送られたことがわかる（川田・安田 2012）。Milkovsky（2010）によ ると, チェコ共和国プラ八の博物館にもオーストンコレクションがあり, その一部は海南島の もの約 55 点というので, 勝間田コレクションは世界中に散逸しているとみてよさそうである。

\section{3)-5. 採集人, 高田 昂}

籾山（1930）に1903年から1904年にオーストンが採集人を派遣したと書かれている。110 ページには「Owstonの採集人高田昂は1904年1-2月母島列島中の母島及姪島にて此種多数を 採集あり。此等はOwstonの手を経て各国の博物館並に蒐集家の許に散布せられ居る筈なり」 と記されている。高田は後に富士山麓の須走でアマチュア鳥類研究者兼鳥寄せの名人として知 られることとなる人物で, 彼が日本野鳥の会主催の探鳥会に父である高田兵太郎とともに参加 し, 中西悟堂, 柳田國男, 北原白秋といった著名人を案内した記録がある（日本野鳥の 会 1934a)。また農林省嘱託として研究にも従事したとあり，1944年2月下旬に72歳で死去し た（日本野鳥の会 1944）。

もう一つ高田が関わった記録として, Ingram（1908）がある。コリンウッド・イングラム （Collingwood Ingram）は英国の鳥類研究家で，1902年と1907年に来日した。1907年の訪問で は4月 20 日に長崎から入国し，5月 14 日以降オーストンの勧めで富士山麓の須走で約 3 週間を 過ごした。現地の採集人と通訳がいたというが, この採集人が高田 昂であったことが日本野 鳥の会 (1934b) に記録されている。通訳はオーストン商会の人であったと思われるが，詳細は 不明である。コジュリンEmberiza yessoensisの記述 (Ingram 1908, p. 155) には，イングラムが 須走を去る際に卵と巣を現地の採集人にお願いしていたところ，6月19日に得られたという連 絡がオーストンにあり，オーストン自身が出向いて2つの巣を持ち帰った，というものがあ る。オーストンが本当に須走まで行ったのかどうかはわからない。

イングラムはこの後満州を経由してウラジオストクからドイツまで旅をした（Ingram 1909)。この時満州の景観に魅せられて, ここの鳥類を調べたくなったらしい。そこで 「My friend」オーストンに日本人採集人を送る計画を立ててほしいと依頼した。採集人として 雇用されたのは後で示すように折居彪二郎である。

\section{3)-6. 二人の「長」とその採集品}

オーストン商会で働いた重要な人物の一人がOsa Masamichi と S. Choである。JDによると, これら二人の人物がオーストン商会に在籍したのはそれぞれ1882-1898年（ただし途中 1885 , 1886, 1897年には名前がない)，1899-1909年となっている（Table 1)。一方で日本紳士録による 
と 1897 年と 1898 年を境として長 政道から長 聖道へと入れ替わっている。おそらくこの二 人の長という人物は同一人物で，この頃改名したのであろうと考えている。ここではこの二人 の「長」という人物についてわかっていることを自然史研究における貢献と共に詳述する。

長 政道が文献上初めて現れるのは，1891年に大日本水産会へ入会したことを示す「會員 諸件」である（大日本水産会 1891b）。この同年，オーストンがウェストや飯島らとともに同 学会で講演を行い, オーストン（1891）としてその記録を残していることはすでに述べた。こ の「漁船卜快船卜ノ関係」という論説は和文で掲載されており, おそらくオーストン商会の誰 かが翻訳したものであったろう。長はオーストン商会の中でこういった学会活動のための役割 も持たされていたように思える。

一方の長 聖道は1904年1月に日本動物学会に入会したことが学会記事に見て取れる（日本 動物学会 1904a, 1904b)。このように長は学会のような場に参加する意欲を持っていた人物で あったことが推察され，他の従業員が同様な活動に全く跡を残していないのと対照的である。

1904年 5 月から長は長田霊瑞（JDの「R. Osada」）という謎の人物を伴って琉球列島の調査 に送り出されている。この記録は江崎 (1984b) などに記録されているが，その収集品が多くの 研究者により調べられたことで知られている。まず鳥類に関しては東京帝国大学の学生であっ た小川三紀により調査され, チェックリストとしてまとめられた（Ogawa 1905）。この中で特 筆すべきはハシブトガラスCorvus macrorhynchos の亜種オサハシブトガラス（原文ではCorvus macrorhynchus osai SUBSP. NOV. (Osagarasu)) Corvus macrorhynchos osaiである。ここで「M. Osa」という名を献名したことにより，小川が「Osa Masamichi（長 政道）」の名を意識して 用いたことが分かる。そのほかの鳥類として特筆すべきものは，このコレクションから記載さ れたオーストンゲラ Picus owstoni（現在はオオアカゲラDendrocopos leucotos の亜種）やリュウ キュウヨシゴイ Nannocnus ijimai (現在はIxobrychus cinnamomeus のシノニム) 等がオーストン や飯島に献名されていること（Ogawa 1905）と, ルリカケスGarrulus lidthiが再発見され, 生 息地が明らかにされたということであろう（飯島 1905）。

Ogawa（1905）によると長と長田は石垣島, 西表島から始まり北上する経路で琉球諸島を探 索し, 11 月から 12 月にかけて最後に訪れた屋久島, 種子島においては採集協力者に標本を 送ってくれるよう依頼した。また彼らが訪れていない与那国島などでも現地の採集人が標本を もたらしたというので, 標本と長の滞在旅程が異なるものがある点に注意が必要である。また 江崎（1984b）によると長田はその後も奄美大島に滞在したと伝えられているというが，その記 録は見つけられていない。

哺乳類標本については東京帝国大学の学生だった石田収蔵が調査し, 動物学雑誌に「琉球に 産する三四の哺乳動物」を書いている（石田 1905）。石田は後に人類学を専攻しアイヌの民族 文化などに業績を残すこととなる人物である（板橋区郷土資料館 2000）。おそらく哺乳類に関 心があったというわけではない様子が文章からもうかがえ，教授陣に書かされた感があふれる 面白い文章である。その後, おそらくこの哺乳類コレクションは英国自然史博物館に送られ た。それを示す証拠として, 奄美大島をタイプ産地として記載されたケナガネズミ Diplothrix legataがある。この種は英国自然史博物館のオールドフィールド・トーマス (Oldfield Thomas）により1906年にLenothrix属の一種として記載されたが，その記載文にオーストンの採集人 「Cho」により採集されたことが明記されている（Thomas 1906）。 
オーストンと英国自然史博物館のトーマスとの関係はこれをさかのぼること 1900 年頃には あったらしい。トーマスは1898年に来日し関西地方を中心として英国自然史博物館のために 標本の収集を行った英国人，リチャード・ゴードンスミス（Richard Gordon-Smith）のコレク ションに関する調查を行い, スミスネズミEothenomys smithiiなどを新種記載した（Thomas 1905)。この中に1900年にオーストンから購入したムササビPetaurista leucogenys の標本に ついても記述している。また英国自然史博物館との関わりとしては, 同館から Duke of Bedford's Zoological Expedition の調査員としてマルコム・アンダーソン（Malcolm Anderson）が日本 に派遣されることとなり，この調査にもオーストンが絡んでいた可能性があるのだが，この件 については採集人の一人である折居彪二郎が登場するまで置いておくことにする。

長はさらに 1905 年 4 月から清国西安へ調査に派遣される。主に太白山等で調査を行うが，そ の記録は動物学雑誌に2回にわたって掲載されている（長 1905, 1906）。長はこの道中, 雇用 した中国人の䛊発砲により左手を打ち抜かれるという事故に遭遇する。長期の入院となり, 左 手三本の指が不自由となったという。この時の回顧で「キリストの愛我れを励まし同情の厚き を感謝せり」と述べていることは，彼がキリスト教信仰にあったことを示している。

長は翌年1月に帰国し, 持ち帰った標本の一部はアメリカ自然史博物館に送られた。哺乳類 標本は 16 種を含む 55 点で, 海南島のコレクションと同様J. A. アレンによって調査され, 新種 も記載されている (Allen 1909a)。特にイワリスの一種Sciurotamias owstoni（現在はイワリスS. davidianusのシノニム) はオーストンに献名された種である。また長はタイリクオオカミCanis lupusの生体も持ち帰っていたらしい。このオオカミとカモシカ類の毛皮標本をシフゾゥ Elaphurus davidianusの角と交換したという記録が上野動物園の『動物録明治39年』に，さら に『動物総目録』には交換以前にこのオオカミを展示のため一時貸出していた記録も残されて いる。鳥類は膨大なコレクションが英国のロスチャイルド動物学博物館へ送られたとみられ, キュレーターのハータートによるコマドリ属Larvivoraに関する記録（Hartert 1907）や，後に はオナガCyanopica cyanaの亜種記載を行っている(Hartert 1917)。

長は1907年に東京へと移動したらしい記録がJDの「S. Cho, Tokyo」に見て取れる（立 脇 1996r)。また動物学雑誌の「転居者」の欄には長 聖道が「東京市日本橋區檜物町十八番 地」の住所に移転したことが記されているので（日本動物学会 1906）, 日本橋にオーストン商 会の支店があったのだろうか。さらに1909年には東京市芝区田町6丁目10へ転居している（日 本動物学会 1909)。この後も1910年5月15日発行の動物学雑誌（日本動物学会 1910）に死亡 記事が掲載されるまで, 長はオーストン商会に所属していた（立脇 1996s）。以上が現在まで 長について知られるところであり, 生まれた年や死亡時の年齢といった情報はまだ得られてい ない。

\section{3)-7. 採集人, 折居彪二郎}

オーストンが雇用, 育成した日本人採集人として, 最も有名なのは折居彪二郎であろう。彼 についてはこれまでに数々の研究成果があり, その経歴については近年出版された『鳥獣採集 家折居彪二郎採集日誌〜鳥学・哺乳類学を支えた男〜』に掲載された正富（2013）を参照され たい。しかし彼がどのような経緯でオーストンと知り合い, どのように付き合っていたのかに ついては謎が非常に多い。ここでは折居とオーストンのかかわりについてまとめてみたい。 
山階（1948）によると，折居は「1906年千島旅行の帰途函館に立ち寄った……Malcolm Andersonの面識を得」たという。アンダーソンは前に少し触れたが, 英国の Duke of Bedford's Zoological Expeditionの採集員として自然史博物館から派遣された米国人である。折居は「Andersonの勧めに従って直ちに横浜に赴き，オーストンと契約した」と記されている。これによれ ば，アンダーソンは来日早々オーストンのことを知っていたことになるが，この頃までに英国 自然史博物館のトーマスへ多くの標本を送ってきた経緯があったからであろうか。

一方で折居の採集日誌によると，折居は1906年10月16日にオーストンに会ったことが記さ れている。折居はオーストンに水産物を渡し，翌日13 円 75 銭を受け取ったとあるので，すで にオーストンの採集人として活動していた可能性も否定できない。19日には再びオーストン を訪問し, 長與からたばこ 10 箱を受け取っている。この後折居はアンダーソンの助手兼通訳 として20日から韓国, 対馬周辺, 中国山東省の調査に出発した。山東省で調査をしていた翌 年 4 月 25 日，折居はアンダーソンの用意した昼食に憤慨し，それまで調査中にたまっていたア ンダーソンへの不満が爆発, ここでオーストンに別の調査に自分を送り出すよう手紙を出して アンダーソンからは暇をもらった，という（鷲田 2013）。

折居が 1906年10月16日にオーストンに渡したという水産物がどこの何であるのかは不明で ある。しかしちょうどこの直前東京帝国大学の飯島はオーストンの「艤装せる船と, 熟練なる 採集人」を使ってサハリンで調査を行っている（永澤 1916）。調査で得られた鳥類標本を調査 したストックホルム博物館のエイナル・ルンベルグ (Einar Lönnberg) によると, コレクション は99種を含む数百点の仮剥製標本と鳥の巣や卵も含む膨大なもので, 飯島とオーストンに対 する謝辞が述べられている（Lönnberg 1908）。これほど膨大な標本を得ることができた採集人 はいったい誰だったであろうか。なお，飯島は7月6, 7 日にサハリンでアンダーソンに会って いる記録がある。そして折居は飯島の推薦で後の鳥類学者黒田長礼の採集人として働くように なる（山階 1948）。一つの可能性として, 飯島のサハリン調査に同行したものが折居であった のではなかろうか。これは今後の課題である。

折居はアンダーソンと別れたのち，1907年6月から 10 月にかけてオーストンの依頼で南千 島に単独で旅行している。その翌年1908年4月から9月まで中国東北部（満州）で調査してい る（正富 2013）。これはイングラムからの依頼をオーストンが仲介したものだった。すでに述 ベたように, イングラムは 1907 年の日本訪問でオーストンと交流しており, 折居にその役割 が与えられたのであろう。この時の採集品の内, 鳥類はイングラムに送られて種のリストがま とめられた（Ingram 1909）。また哺乳類は英国自然史博物館に送られたようで, トーマスが調 査していくつかの亜種が記載されている（Thomas 1909）。後にトーマスはThomas（1909）で 既知種と同定したモグラレミングの一種Myospalax epilanus を新種記載した（Thomas 1912a)。 これらの論文で調査された標本はオーストンの採集人「Orie」が採集したと書かれており，こ の頃までトーマスは折居の名前を間違えていたものと思われる。また1912年の論文でトーマ スはもう一種別のモグラレミングMyospalax fontanus を記載しており（Thomas 1912a），このタ イプ標本はアンダーソンが採集したものであったというのも，折居としては皮肉なことであっ たろう。

さらに折居は1909年6月から 11 月までサハリン調査へ行き, おそらくその成果は東京帝国 大学の内田清之助が鳥類についてまとめたもの（内田 1910）に相当すると思われるが, 採集 
者のことについては触れられていない（内田(1912）も参照のこと）。翌1910年2月から翌年 8 月まで, 中国雲南省から現在のベトナム北部トンキン地方へと採集旅行に送られたとされてい る（正富 2013）。途中でオーストン商会が財政難に陥り資金送金が途絶え，小林桂助（二代 目）の援助を受けて調査を継続したという（山階 1948）。結果としてこの調査で得られた標本 の一部は，オーストンを経由して鳥類がイングラムへ，哺乳類がトーマスとガイ・ドールマ ン（Guy Dollman）へと送られて調査されている。Ingram（1912）では1910年3月から7月にか けての鳥類がまとめられているが, 冒頭でイングラムはオーストンが 1910年の夏に日本人採 集人を雲南省南部に送ったこと,「この男がかなり膨大なコレクションを得た」ことを述べて いる。しかしながら, それらの大部分が正当な権利を有さないものの手に落ち, 残りの標本が オーストンから手元に届いたと憤慨している。また, Ingram（1912）はロスチャイルドの許可 を得てまとめたとのことが書かれており，この調査の資金はロスチャイルドが支出していたこ とがうかがわれるが，調査資金が途絶えたということが本当にあったのだろうか。

折井とオーストンおよび小林の標本のやり取りについて，さらに謎は深まるが，トーマスは オーストンヘミガルスChrotogale owstoni を新種として記載した（Thomas 1912b)。タイプ標本 は1911年9月16日に現在のベトナム北部に位置するYen Baiで「Mr. Alan Owston's collector Orii」（ここでようやくOrii と正しく表記されるに至る）により採集されたとしている（Thomas 1912c)。同様にドールマンはトンキンシシバナザルRhinopithecus avunculus を新種記載 し（Dollman 1912a），その後に発表された記載文によるとタイプ標本は1911年9月14日に上記 オーストンへミガルスと同じ場所, 人物により採集されたことが書かれている（Dollman 1912b)。これらの日付はこれまでに知られているところでは, 折居がすでに調查旅行を 終えた後ということになるだけでなく, 調査の後半は小林桂助に標本が送られたはずだが, な ぜこれら2種のタイプ標本となる個体がオーストンから英国に送られたのだろうか。その他に もトーマスによる記載はThomas（1912d）のジネズミの一種Crocidura dracula（現在ではスス イロジネズミC. fuliginosaのシノニム）とムササビの一種Petaurista marica（現在はシロフムサ サビP. elegansのシノニム）の記載, Thomas（1914）のツパイの新亜種 Tupaia belangeri yunalis （和名なし，タイプ標本は1910年7月10日雲南省Mong-tszeで折居採集）, Thomas（1916）のカ オナガリスの一新亜種Dremomys pernyi flavior（日時不明, 折居採集, D. pernyiには後述台湾産 のD. p. owstoni という亜種もあり，オーストンカオナガリスの和名が一般に使用されている) の記録といったものがあるが，いずれもオーストンと小林のいずれを経由したものかは論文か らは判別できなかった。ところがThomas（1920）におけるホオジロシマリスの一種Tamiops inconstans（現在はヒマラヤホオジロシマリス T. mcclellandiiのシノニム）の記載論文では, 折居 が雲南入りする前の 1910 年1月31日に採集したものが小林桂助経由で購入された，と明記さ れている。トーマスは雲南, トンキン産の標本の購入元や日付を間違えていた可能性もあり, 今後調査が必要である。

なお米国の哺乳類学者グローバー・アレン（Glover M. Allen）は雲南省, トンキン地方の哺 乳類に関する記録を残しており（Allen 1912）これろは1911年2月の採集品に基づいている。 採集者や送り主については論文中に記述がないが，記載された標本の所蔵先であるハーバード 大学比較動物学博物館のデータベースによると, 標本台帳に「Kobayashi」によって採集され たと記されているので折居の収集品である可能性が高い。各地の博物館に所蔵されている標本 
と台帳の情報を整理することによって，今後詳細に調べる必要がある。

\section{3)-8. 台湾の採集人}

Kuroda（1952）によると，台湾で哺乳類標本の収集を行った二人の人物として，折居ととも に菊池米太郎の名を挙げている。菊池はやはりオーストンの採集人であったといわれており, キクチハタネズミMicrotus kikuchiiに名前を残すとともに, ウォルター・グッドフェロー（Walter Goodfellow）が台湾から持ち帰った飾り羽をもとに記載されたミカドキジ Syrmaticus mikado を初めて捕獲した人として知られる。

山崎（1992）によると，菊池は1906年に37歳で台湾総督府殖産局の職員として台湾入りする 前に, 海南島でドイツ人から鳥獣の採集と標本作成を学んだとされている。台湾ではかなり奥 地まで調査を行ったとみえ，台湾の自然史標本収集に活躍したようだが，その記述はあまりな い。

オーストンが台湾から得た哺乳類標本は英国自然史博物館へ送られ，トーマスはムササビの 一種Petaurista lena（現在はカオジロムササビP. alborufus の亜種）を記載しており，その採集 者を「Native Hunter」がオーストンのために採集，としている（Thomas 1907）。同様にトーマ スは台湾のアカネズミ属Apodemus とノウサギ属Lepusを記載した（Thomas 1908a)。タイワン アカネズミApodemus semotusは阿里山にて1906年11月13日, 採集者は「Alan Owston's native collector」としている。ノウサギ属の一種Lepus formosus（現在はシナノウサギL. sinensisの亜 種）のタイプ標本はP. A. ホルスト（P.A. Holst）の採集品で, 参考標本として阿里山産個体を記 録している。またトーマスはオーストンに献名した新属新種のZetis owstoni を記載（Zetis は現 在ではカオナガリス属Dremomys のシノニムでオーストンカオナガリスと亜種ランクになって いる）しており，タイプ標本は1906年12月6日阿里山でやはりオーストンの「native hunter」 が採集とある（Thomas 1908b）。これらはおそらくオーストンの採集人としてこの年に台湾入 りした菊池の仕事であったろうことが推測される。Thomas（1913）にも菊池と思われるオース トンの採集人により捕獲された標本が紹介されている。

菊池がオーストンの採集人として文献上はじめて登場するのは波江（1908）と思われる。「臺 灣産毒蛇」の「一、百歩蛇」において浪江は「アラン, オーストン氏の採集人菊池某の該地に 在りて‥」及び「幸いにも同氏は昨年四月（4月11日と26日に捕里にて）該蛇二頭を捕獲せ る由物語しとの報道に接し直にオーストン氏の許へ照会せしに早速其標本を送付せられし を‥」とある。1907年4月には菊池は間違いなくオーストンの採集人として台湾で標本収集を 行っていたことがわかる。内田は，「横浜のA. オーストン氏と台北博物館のY. Kikuchi氏から の寄贈品 (donations)」として台湾産鳥類のチェックリストをまとめている (Uchida 1912)。こ こでオーストンと菊池の寄贈品として別に書いており, 菊池はこの頃すでに独立して標本を提 供していたように思われる。菊池は1921年に52歳で亡くなったというが, Kuroda（1952）に よると，厳しい亜熱帯での度重なる重労働のため早逝したとのことである。

\section{3)-9. オーストン死後の自然史標本}

自然史標本のその後について，1921年2月17日，3月20日，4月2日にオーストンの鳥類標 本がアメリカ自然史博物館に買い取られる可能性があるとする記事が 3 回に分けて朝日新聞に 
掲載されている。日本の博物学の未熟さを嘆く文章で, その後コレクションが本当に外国に買 い取られたのかどうかについては追跡記事が見つからなかった。ただし, 掲載紙及び掲載日不 明の新聞記事が筆者の手元にあり（鈴木一義氏提供資料, 文脈からカナダのバンクーバーの日 本人向けに書かれたもののようである), そこには「死後, そのうちの鳥の標本が日本の鳥学 の権威, 内田清之助氏並びに黒田侯爵嗣子に引き取られた」またほかの標本は「キャプテン・ フランシス・オーストンによって, 日本政府に寄贈され」と記されている。この記事の著者は 不明であるが,「私の學生時代に, 飯島教授の依頼を受けて, 同氏の伝記を書き, 生物學の専 門雑誌に掲載したことがある」と書いているので, 動物学雑誌に追悼文（永澤 1916）を記し た永澤六郎によるものである可能性が高い。永澤は東京帝国大学で飯島の指導を受け，アワビ 類の生態, 発生を卒業論文の題目としていたが, あまり研究に向かなかったようで, オースト ンが死亡した頃動物学雑誌の編集を任されていたらしい。ところがある時突然教室を去り, 動 物学雑誌の発行に支障をきたしたという。その後シアトルで永澤に再会した者があり, 彼が新 聞の出版に携わっていたというので（大島 1967），十分に可能性はあるだろう。

今一つその後の動向について，1923年9月1日の関東大震災で多くの研究機関に所蔵されて いた自然史標本が被害にあった。オーストン由来のコレクションに関しても, 農商務省が全焼 し，「完全さを誇っていた鳥獣のオーストン・コレクション」が焼失したと磯野（1988）に書か れている。ところがオーストンのコレクションの一部は震災を逃れて農商務省の後身である森 林総合研究所や山階鳥類研究所, 国立科学博物館といった研究機関に少なからず残されてい る。これらがどのような経緯でこれらの機関に保管されるに至ったかについては今後調べる必 要があろう。

震災から数年後, 1929 年 4 月 5 日付横濱貿易新報及び都新聞に「ドクターアーレン・オース キン」氏（都新聞では「ドクター・アーレン・オーストン」となっている）が収集した標本を 天皇陛下が横浜行幸の際にご覧になりたいという「御内命」があった，という記事がある。こ の時横浜市では「神奈川県立第一中学校」に標本が保管してあることが分かったそうで,「オー ストン氏は‥帰国に際して将来の教育資料として県立第一中学校に寄贈したものである」とあ ることから，兄フランシスが寄贈したのではなかろうか。そこから数百点を陳列して「聖覧に 供へる」ことになったのだという。このような事態になり，オーストンがどのような人物なの か調べたというが，十分な情報は得られなかったようだ。1929年4月24日の朝日新聞夕刊に よると，「英人故オーストン氏が縣下で収集採取した海綿站に動物標本約百十五點を天覧に供 し奉ったが生物學にご研究深き陛下にはいともご熱心に御覧あらせられた」とこの「天覧」は 無事執り行われたようである。しかしその後このコレクションがどうされたのかについても不 明である。

\section{4) まとめと今後の調査課題}

オーストンは日本産鳥類標本の提供を, ブラキストンやプライアといった在日外国人との個 人的関係のもとに 1882 年頃から開始し, また米国から採集のために来日したジューイの採集 にも協力した。ジューイが米国へ持ち帰った標本には多くの哺乳類標本も含まれ（河 合 2012)，これらについてもオーストンが協力したのかどうかは判定できないが，オーストン の日本でのナチュラリストとしてのキャリアを鳥類分野から開始したことは間違いなさそうで 
ある。1890年代になるころにはすでに大量の標本を収集して英国などにも送付し，ロスチャ イルドのコレクションの充実にも貢献しており，その後東京帝国大学との交流が始まったこと から，日本の鳥類学黎明期への寄与もなされた。1890年代前半にはすでに自然史標本ディ一 ラーとしての業務を取り入れて, 他の分類群の動物標本収集が行われるようになり, 日本人採 集人の教育及び僻地派遣により事業はさらに拡大されていった。採集人による調査旅行では, 鳥類のほかにも様々な動物種も収集させたことが明らかであり, 例えば折居による雲南調査で は得られたすべての動物の精査により旅程などが明らかにされ，それによって鳥類の採集デー タなどを補完することが可能となるかもしれない。

本稿ではオーストンの活動について, 鳥類以外の哺乳類や水産物といった動物について既存 の文献資料をまとめたが, 彼が国内外の研究機関に提供, 販売した標本類については, 網羅的 に調べつくせていない現状がある。オーストンは昆虫類についても標本収集を行い，ロスチャ イルドへの販売を行っていたというが, その詳細を記す文献は未調査である。昆虫学への貢献 に関しては述べなかったが, 江崎 (1984b) によると, 長 聖道と長田霊瑞によって琉球で収集 されたセミ類の標本は, 北海道帝国大学の松村松年によって調べられたとされている。また米 国自然史博物館のウイリアム・モートン・ウィーラー（William Morton Wheeler）が記載したア リの一種にオーストンに献名されたハヤシナガアリStenamma owstoniがあるが，この論文の冒 頭で，1904年夏から 1905 年春にかけて「Haus Sauter」が岡山や神奈川で採集したものをオー ストンが送ってくれたという記述がある（Wheeler 1906）。「Haus」は「Hans」の間違いで，台 湾で昆虫商として活躍したハンス・ザウター（Hans Sauter）のことと思われる（江崎 1984a） が, ザウターとオーストンの関係についても調査が必要である。

さらに1906年 12 月 15 日発刊の昆蟲世界第 10 巻第 12 冊（第 112 号）に『名和日本昆蟲圖説第 一巻』に関する名和昆虫研究所の広告がある（Fig. 8)。この本は1904年に同研究所から初版が 出版されたが，その後動物学雑誌上で英語に誤謬があると忠告されたらしい。そこで「アラ ン, オーストン氏監督の下に歐文全部を訂正改版の上出版し其後オーストン商店に於て販賣す ること」になったとのことである。残念ながら筆者はこの改訂版を未見であるが，オーストン 自身による文章が含まれる可能性もあるため今後調査する必要がある。

以上のように昆虫学関連でも当時の研究者や外国人採集人との関係があったようで, オース トンの守備範囲は想像以上である。鳥類学におけるオーストンの貢献を理解するためには, 他 分野での活動内容を含めた全体像を知ることが肝要であろう。特にオーストンが初期の頃から 本業としていたという鉄鋼関連の情報や，発動機漁船の開発といった内容に関しては今のとこ ろ知られるところが多くない。オーストン商会の業務実績といったものはどのようなもので あったのだろうか。オーストン商会の初期にオーストンが鳥類標本などを来日した外国人や帝 国大学へ提供することができたのは, 本来の事業が成功していたことによる「余裕」ととらえ ることもでき，その後の自然史ディーラーとしての事業拡大がどのように影響したのかについ ても興味が持たれるところである。

本論では主に文献情報を取りまとめる目的として執筆されたものであるが，まだ未公開の書 簡資料なども国内外には保存されていると思われる。今後資料の分析をより詳しく進めていき たい。オーストンの死後 100 年を経て, オーストン研究の活発化を期待するところである。 


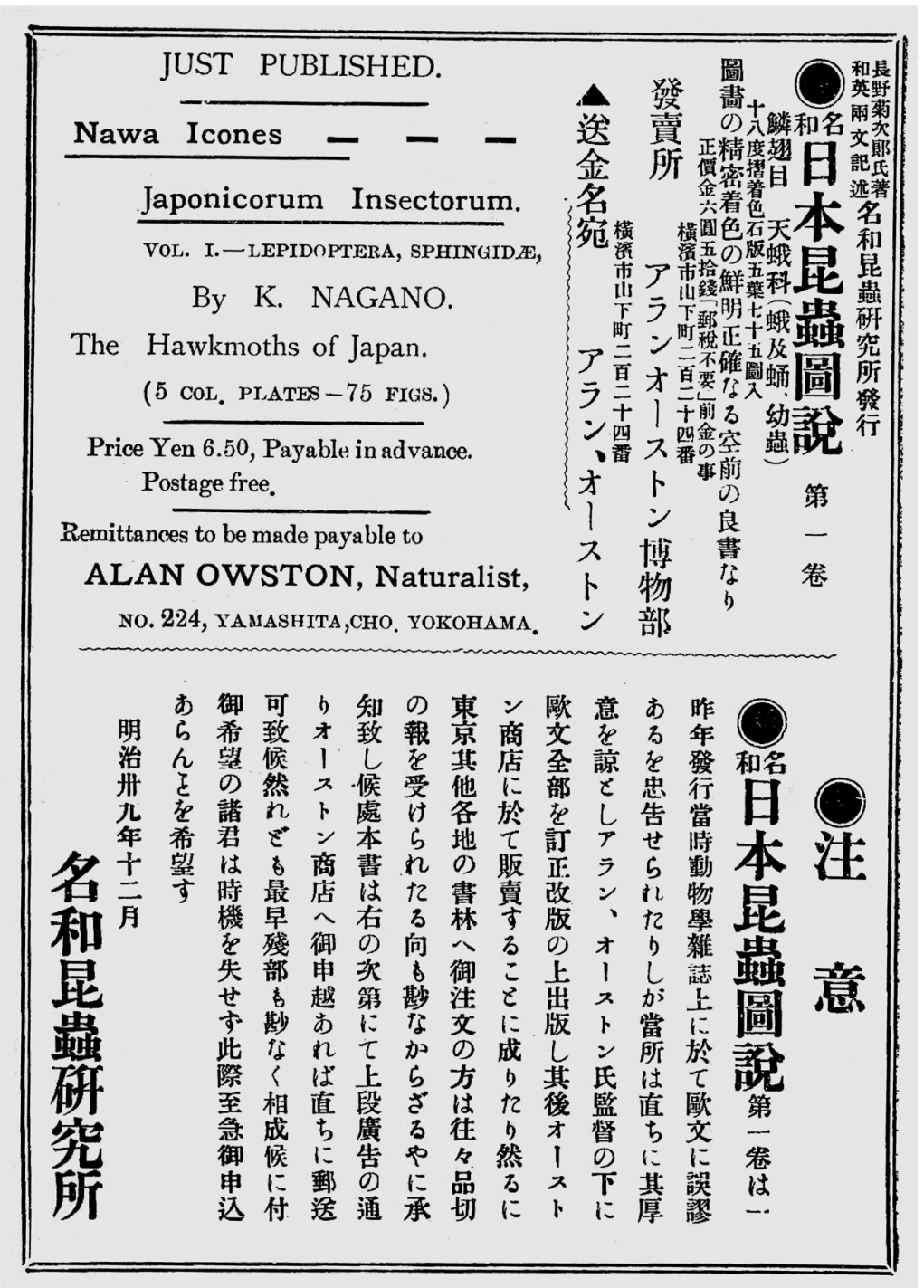

Fig. 8. Advertisement of the new edition of Nawa Icones Japonicorum Insectorum inserted in The Insect World No. X, Vol. 12.

図 8. 昆蟲世界第 10 巻第 12 冊（第 112 号）に掲載された『名和日本昆蟲圖説』の広告.

謝辞

本論文をまとめるに当たり，横浜開港資料館，横浜新聞博物館，東京動物園協会，国立国会 図書館, 筑波大学図書館の所蔵資料を閲覧した。ここに記して御礼申し上げる。国立科学博物 館理工学研究部の鈴木一義氏からは, オーストンにかかわるいくつかの新聞記事とオーストン 
商会の広告を提供いただいた。岐阜県立博物館の説田健一氏からはJDの「K. Nagayo」につい て有益な情報をいただいた。岡山理科大学の小林秀司氏からは勝間田善作についての雑誌記事 を紹介していただいた。国立科学博物館動物研究部の山田 格氏, 藤田敏彦氏からはそれぞれ スノーとオーストンの英国での学歴に関する文献の提供をいただいた。筆者の研究室補助員の 長岡浩子氏, 下稲葉さやか氏 (現所属千葉県立中央博物館), 及び岐阜県水上市在住の博物学 史研究家平田逸俊氏には文献の調査を一部手伝っていただき，また資料の取りまとめにあたり 多くの助言をいただいた。最後に査読者の一名からは, 筆者が知りえなかった文献の提示をい ただき，また筆者の思い込みで記述してしまった内容について多くのご指摘をいただいた。深 く御礼申し上げる。本研究は文部科学省科学研究費基盤 $\mathrm{C}$ (日本の動物学におけるアマチュア ナチュラリストの役割, 課題番号：26350373）により行われた。

\section{摘 要}

アラン・オーストンは明治期の日本においてもっとも著名なナチュラリストの一人として自 然史分野に知られる人物である。彼の貢献は過去の文献に紹介されているが，いずれも詳しい 人物像などについては概略的情報しか示されていなかった。本総説では自然史分野のみならず 技術史的な側面についても学術論文, 学会記事, 新聞記事などをもとに彼の業績を取りまと め, 特に当時の各方面研究者との交流関係や, 彼が横浜に開いたオーストン商会で雇用した人 物などにも焦点を当てて詳述した。これらの基礎資料が明治期日本の技術史や自然史研究にお ける発展の解明に向けた一助となることを期待する。

\section{引用文献}

Allen, G. M. 1912. Mammals from Yunnan and Tonkin. Proceedings of the Biological Society of Washington 25: 177-179.

Allen, J. A. 1906. Mammals from the island of Hainan, China. Bulletin of American Museum of Natural History 22: 463-490 + P1. LXIX.

Allen, J. A. 1909a. Mammals from Shen-si Province, China. Bulletin of American Museum of Natural History 26: 425-430.

Allen, J. A. 1909b. Further notes on mammals from the island of Hainan, China. Bulletin of American Museum of Natural History 26: 239-242.

Asiatic Society of Japan 1874. List of members. Transactions of the Asiatic Society of Japan 1: ページ数なし.

Asiatic Society of Japan 1878. List of members. Transactions of the Asiatic Society of Japan 6: ページ数なし.

Baird, S. F. 1885. Report of Professor Baird, Secretary of the Smithsonian Institution for 1883. In Annual Report of the Board of Regents of the Smithsonian Institution Showing the Operations, Expenditures, and Condition of the Institution for the Year 1883 (ed. Smithsonian Institution), pp. 1-86. Government Printing Office, Washington D. C.

Bangs, O. 1901a. On a collection of birds from Liu Kiu islands. Bulletin of the Museum at Harvard College 36: 255-269.

Bangs, O. 1901b. Notes on a small collection of mammals from the Liu Kiu Islands. The American Naturalist $\mathbf{3 5}$ : 561-562.

Barbour, T. 1908. Some new reptiles and amphibians. Bulletin of Comparative Zoology 51: 315-325.

Barrett-Hamilton, G. E. H. 1900. On the variable hare. Proceedings of the Zoological Society of London 1900: 87-92.

Bean, B. A. 1905. Notes on an adult goblin shark (Mitsukurina owstoni) of Japan. Proceedings of the United States National Museum 28: 815-818.

Blakiston, T. W. \& Pryer, H. 1880. Catalogue of the birds of Japan. Transaction of the Asiatic Society of Japan 8: 172-241. 
Blakiston, T. W. \& Pryer, H. 1882. Birds of Japan. Transaction of the Asiatic Society of Japan 10: 84-186.

長 聖道 1905. 清國西安府より長聖道氏の音信. 動物学雑誌 17: 266-267.

長 聖道 1906. 清國西安府より長聖道氏の音信：第十七卷二百六十七頁より續く. 動物学雑誌 18: 68-72.

Clark, A. H. 1908a. On a collection of feather stars, or comatulids, from Japan. Proceedings of the United States National Museum 34: 305-319.

Clark, H. L. 1908b. Some Japanese and East Indian echinoderms. Bulletin of the Museum of Comparative Zoology 51: 279-311.

大日本水産会 1891a. 本會記事. 大日本水産会報 (109): 261-274.

大日本水産会 1891b. 本會記事. 大日本水産会報 (111): 379-384.

大日本水産会 1911. 一月中會員入退會數. 大日本水産会報 (141): 64-65.

Dollman, G. 1912a. No title. Abstract of the Proceedings of Zoological Society of London 1912: 18.

Dollman, G. 1912b. A new snub-nosed monkey. Proceedings of Zoological Society of London 1912: 503-504.

江崎悌三 1984a. 第二回台湾採集旅行記. 江崎悌三著作集 3 (上野益三ほか共編), pp. 43-114. 思索社, 東京.

江崎悌三 1984b. 奄美大島の概観. 江崎悌三著作集 3 (上野益三ほか共編), pp. 115-170. 思索社, 東京.

Garman, S. 1906. New Plagiostomia. Bulletin of the Museum of Comparative Zoology at Harvard College 46: 203208.

Goto, S. 1914. A descriptive monograph of Japanese Asteroidea: 1. Archasteridae, Benthopectinidae, Porcellanasteridae, Astropectinidae, Luidiidae, Pentagonasteridae, Oreasteridae, Gymnasteriidae, Asterinidae. The Journal of the College of Science, Imperial University of Tokyo, Japan 29 article 1: 1-808 +19 pls.

Günther, A. 1906. The History of the Collections Contained in the Natural History Departments of the British Museum Vol. II. British Museum, London.

Hartert, E. 1907. On some rare species of the genus Larvivora from China. Ibis 49: 621-623.

Hartert, E. 1910. The birds of Hainan. Novitates Zoologicae 17: 189-254.

Hartert, E. 1917. The subspecies of Cyanopica cyanus. Novitates Zoologicae 24: 493.

林 正敏 1991. 鳥学を支えた岳人. 信濃每日新聞社, 長野.

北海道大学北方生物圏フィールド科学センター植物園 2002. T. W. ブラキストン鳥類目録. 北大植物園資 料目録第 2 号.

飯島 魁 1893. やまからノ新種二就テ. 動物学雑誌 5: 445-446.

飯島 魁 1894a. 小笠原島産からすばと一種二就キテ. 動物学雑誌 6: 24-26.

飯島 魁 1894b. いはみせきれい二就キテ. 動物学雑誌 6: 26-27.

Ijima, I. 1894. Notice of new Hexactinellida from Sagami Bay. Zoologischer Anzeiger 19: 249-254.

飯島 魁 1905. 瑠璃樫鳥 (Garrulus lidthi Bp.) の記. 動物学雑誌 17: 143-146.

Ingram, C. 1908. Ornithological notes from Japan. Ibis 50: 129-169.

Ingram, C. 1909. The birds of Manchuria. Ibis 51: 422-469.

Ingram, C. 1912. The birds of Yunnan. Novitates Zoologicae 19: 269-310.

石田収蔵 1905. 琉球に産する三四の哺乳動物. 動物学雑誌 17: 205-207.

磯野直秀 1988. 三崎臨海実験所を去来した人たち. 日本における動物学の誕生. 学会出版センター, 東京. 板橋区郷土資料館 2000. 石田収蔵，謎の人類学者の生涯と板橋. 板橋区郷土資料館，東京. 伊藤保二 1937. 開港時代文化伝来史話. 花束社, 横浜.

Jordan, D. S. 1898. Description of a species of fish (Mitsukurina owstoni) from Japan, the type of a distinct family of lamnoid sharks. Proceedings of the California Academy of Sciences, Ser. 3, 1: 199-204 + pls. XI, XII.

Jordan, D. S. \& Snyder, J. O. 1901. A review of the apodal fishes or eels of Japan, with a description of nineteen new species. Proceedings of the United States National Museum 23: 837-890.

Jordan, D. S. \& Snyder, J. N. 1904. On a collection of fishes made by Mr. Alan Owston in the deep waters of Japan. Smithsonian Miscellaneous Collection 45: 230-240+ pls. LVIII-LXIII.

Jordan, D. S. \& Starks, E. C. 1907. List of fishes recorded from Okinawa or the Riu Kiu Islands of Japan. Proceedings of the United States National Museum 32: 491-504.

Jouy, P. L. 1884. Ornithological notes on collections made in Japan from June to December, 1882. Proceedings of United States National Museum of Natural History 6: 173-318.

株式会社新井清太郎商店 1979. 株式会社新井清太郎商店九十年史. 株式会社新井清太郎商店, 横浜.

加藤 克 2006. 明治初期の「自然史」通詞野口源之助：ノグチゲラの名前の由来 (試論). 北大植物園研 
究紀要 $(6): 1-24$.

川田伸一郎・安田雅俊 2012. 標本をめぐる採集人と貿易商と収集家一ハイナンモグラのラベルを読み解 <一. 哺乳類科学 52: 257-264.

河合久仁子 2012. 一人の採集人が残したもの〜アメリカ・スミソニアン協会国立自然史博物館と大町市の つながり〜。 山と博物館 57 (10): 2-6.

国立科学博物館 1998. 写真で見た国立科学博物館 120 年の歩み. 国立科学博物館, 東京.

駒井 卓 1919. 浮游性紐蟲 (珍奇動物其六). 動物学雑誌 31: 294-296.

Kuroda, N. 1952. Mammalogical history of Formosa, with zoogeography and bibliography. Quarterly Journal of the Taiwan Museum 5: 267-304.

黒田長禮 1953. 採集者寺岡直君の業績. 鳥 13 (62): 1-3.

Lönnberg, E. 1908. Contribution to the Ornis of Saghalin. Journal of the College of Science, Imperial University, Tokyo, Japan 23, article 14: 1-69.

正富宏之 2013. 折居彪二郎評伝 折居彪二郎をめぐって. 鳥獣採集家折居虎二郎採集日誌〜鳥学・哺乳類 学を支えた男〜（正富宏之・加藤 克監修）, pp. 7-71. 一耕社出版，苫小牧.

Mathews, G. M. \& Iredale, T. 1915. On some petrels from the north-east Pacific Ocean. Ibis 57: 572-609.

Mlikovsky, J. 2010. Birds from extra-European expeditions in the collections of the National Museum, Prague, Czech Republic. In Proceedings of the Sixth European Bird Curators Meeting. Journal of Afrotropical Zoology, Special Issue (eds. M. Louette, G. Cael \& W. Tavernier), pp. 65-76. Royal Museum for Central Africa, Tervuren.

籾山徳太郎 1930. 小笠原諸島立垃硫黄列島産の鳥類に就て. 日本生物地理学会会報 1: 89-186.

Mortensen, T. 1904. On some Echinothurids from Japan and the Indian Ocean. Annals and Magazine of Natural History 7 th Ser. 14: 81-93.

長沼依山 1940. 海南島の開發者勝間田善作翁傳. 實話讀物 9(7): 18-33.

長沼依山 1943. 海南島の開發者勝間田善作. 三省堂, 東京.

永澤六郎 1916. 故アランオーストン君. 動物学雑誌 28: 前 3-前 5.

波江元吉 1897. あるばとろーす號 横須賀二觀儿記. 動物学雑誌 9: 55-61.

波江元吉 1908. 臺灣産毒蛇. 動物学雑誌 20: 192-194.

日本鳥学会 1923. 雑報. 鳥 3: 333-337.

日本動物学会 1891a. 相州三崎帝國大學臨海實驗所概况. 動物学雑誌 3: 378-379.

日本動物学会 1891b. ウエスト氏ノ厚情. 動物学雑誌 3: 379-380.

日本動物学会 1894. 相州三浦三崎帝國大學臨海實驗所. 動物学雑誌 6: 193-194.

日本動物学会 1896. 相州三浦三崎帝國大學臨海實驗場. 動物学雑誌 8: 352-353.

日本動物学会 1900a. 東京動物學會記事. 動物学雑誌 12: 155 .

日本動物学会 1900b. ジョーダン氏歓迎會, 東京動物學會記事. 動物学雑誌 12: 267.

日本動物学会 1903. 三崎夏季日誌. 動物学雑誌 15: 416-421.

日本動物学会 1904a. 會報. 動物学雑誌 16: 159-160.

日本動物学会 1904b. 會報. 動物学雑誌 16: 200-202.

日本動物学会 1906. 會報. 動物学雑誌 18: 344-346.

日本動物学会 1907. 明治四十年夏期休暇三崎臨海実驗所日誌. 動物学雑誌 19: 313-317.

日本動物学会 1909. 會報. 動物学雑誌 21: 421.

日本動物学会 1910. 會報. 動物学雑誌 22: 322-323.

日本動物学会 1915. 鳥學會の南洋採集者派遣. 動物学雑誌 27: 108 .

日本野鳥の会 1934a. 富士山麓探鳥會の記. 野鳥 1: 241-242.

日本野鳥の会 1934b. 新執筆家の横顔. 野鳥 2: 466 .

日本野鳥の会 1944. 消息. 野鳥 11: 184.

西川藤吉 1896. 奇妙なる動物. 動物学雑誌 8: 307-309.

Nugent, J. 1982. The world's great department stores. Since 1850, entertainers and friends of the family and community. The Rotarian 14: 26-31, 51-53.

Ogawa, M. 1905. Notes on Mr. Alan Owston's collection of birds from the islands lying between Kiushu and Formosa. Annotationes Zoologicae Japonenses 5: 175-232.

小川三紀 1906. 臺灣綿花島にて護たる數種の鳥類. 動物学雑誌 18: 125-131.

大島 廣 1967 . 三崎の熊さん。新教出版社, 東京. 
オーストン，A. 1891. 漁船ト快船卜ノ関係. 大日本水産会報 (111): 390-393.

オーストン, A. 1898. アマツバメ（Cypselus pacificus）に付きて. 動物学雑誌 10: 26 .

オーストン, A. 1907. 改良漁船に就いて. 大日本水産会報 (298): 18-22.

オーストン, A. 1909a. 漁船研究会の提案に答了。大日本水産会報 (316): 40-41.

オーストン, A. 1909b. 佛國の鰛漁業と發動機漁船. 大日本水産会報 (318): 29-30.

オーストン，A. 1982. 横浜におけるヨット遊び。市民グラフ横浜 (41): 21-24. [『ジャパン・ガゼット』 1909年7月特集号からの訳]

Owston, A. 1899. Swallows in mid-winter. Annotationes Zoologicae Japonenses 3: 29.

Owston, F. 1844. Anecdote of a hen song thrush nursing a young missel thrush. Zoologist 2: 444.

Parisi, B. 1917. I Decapodi giapponesi del Museo di Milano, V. Galatheidea e Reptantia. Atti Della Societa Italiana di Sciense Naturali 56: 1-24. (in Italian)

Peters, J. L. 1933. Outram Bangs, 1863-1932. The Auk: A Quarterly Journal of Ornithology 50: 265-274.

Pryer, H. 1883-1885. A catalogue of the Lepidoptera of Japan. Transaction of the Asiatic Society of Japan 11: 216242, 12: 35-103, 13: 22-68.

Rothschild, L. W. 1895. A new species of rail. Novitates Zoologicae 2: 181.

佐藤貞雄 1940. 機械商秘史. 工業読物社，東京.

佐藤利男 1997. 横浜の隕石ブローカーA.オーストン. 天界 (741): 46-47.

説田健一・時田健一 2005. 明治から大正にかけて活躍した標本商, 長與について. 岐阜県博物館調査研究 報告 (26): 35-44.

品川幸雄 1939. 海南島唯一の邦人 四十年奮闘の勝間田善作兄弟. 実業の日本 42(6): 84-89.

白崎謙太郎 1988. 日本ヨット史，文久元年～昭和 20 年. 舵社，東京.

Snow, H. J. 1897. Notes on the Kuril Islands. John Murray, London.

Snow, H. J. 1910. In Forbidden Seas. Edward Arnold, London.

Spencer Jones, M. E., Scholz, J., Grischenko, A. V. \& Fujita, T. 2011. Japanese bryozoans from the Meiji Era at the Natural History Museum, London, part 1: the Mitsukuri and Owston collections. In Annals of Bryozoology 3: Aspects of the History of Research on Bryozoans (eds. P. N. Wyse Jackson \& M. E. Spencer Jones), pp. 143157. International Bryozoology Association, Dublin.

Stejneger, L. 1897. Description of a new species of guillemot from the Kuril Islands. Auk 14: 200-201.

Stejneger, L. 1905. A new species of lizard from the Riukiu archipelago, Japan. Smithsonian Miscellaneous Collection 47: 294-295.

Stejneger, L. 1907. Herpetology of Japan and adjacent territory. Bulletin of the United States National Museum (58): 1-577.

スノー, H. J. 1980. 千島列島黎明記（馬場 脩・大久保義昭訳）。講談社，東京.

田中茂穂 1905. ギンザメ類. 動物学雑誌 17: 353-369.

Tanaka, S. 1905. On two new species of Chimaera. Journal of the College of Science, Imperial University, Tokyo, Japan 20: $1-14+2$ pls.

田中茂穂 1908. 日本産ギンザメ類. 博物之友 8: 65-68.

Tanaka, S. 1908. Notes on some Japanese fishes, with descriptions of fourteen new species. Journal of the College of Science, Imperial University, Tokyo, Japan 23: 1-54+ 4 pls.

田中茂穂 1910. 二種の深海魚に就て. 動物学雑誌 22: 251-256.

立脇和夫（監修）1996a. 幕末明治在日外国人・機関名鑑 Japan Directory 1（1861-1875）. ゆまに書房，東京.

立脇和夫（監修）1996b. 幕末明治在日外国人・機関名鑑 Japan Directory 2（1876-1878）. ゆまに書房，東京。

立脇和夫（監修）1996c. 幕末明治在日外国人・機関名鑑 Japan Directory 3 （1879-1880）. ゆまに書房，東京.

立脇和夫 (監修) 1996d. 幕末明治在日外国人・機関名鑑 Japan Directory 4 （1881-1882）。沛まに書房，東京。

立脇和夫（監修）1996e. 幕末明治在日外国人・機関名鑑 Japan Directory 5（1883）。ゆまに書房，東京.

立脇和夫（監修）1996f。幕末明治在日外国人・機関名鑑 Japan Directory 8 （1886）。ゆまに書房，東京.

立脇和夫（監修）1996g. 幕末明治在日外国人・機関名鑑 Japan Directory 10（1889）。ゆまに書房，東京.

立脇和夫（監修）1996h. 幕末明治在日外国人・機関名鑑 Japan Directory 14（1892）。ゆまに書房，東京.

立脇和夫（監修）1996i．幕末明治在日外国人・機関名鑑 Japan Directory 16（1894）。ゆまに書房，東京.

立脇和夫（監修）1996j. 幕末明治在日外国人・機関名鑑 Japan Directory 17（1895）。ゆまに書房，東京.

立脇和夫（監修）1996k. 幕末明治在日外国人・機関名鑑 Japan Directory 18 （1896）。まに書房，東京. 
立脇和夫（監修）19961. 幕末明治在日外国人・機関名鑑 Japan Directory 19（1897）。沁まに書房，東京. 立脇和夫（監修）1996m. 幕末明治在日外国人・機関名鑑 Japan Directory 21（1899）。吣に書房，東京. 立脇和夫（監修）1996n. 幕末明治在日外国人・機関名鑑 Japan Directory 22（1900）。泌まに書房，東京. 立脇和夫（監修）19960. 幕末明治在日外国人・機関名鑑 Japan Directory 27（1902）。吣に書房, 東京. 立脇和夫（監修）1996p. 幕末明治在日外国人・機関名鑑 Japan Directory 29（1903）。沁に書房，東京.

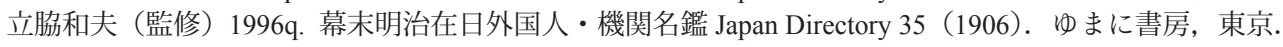
立脇和夫（監修）1996r. 幕末明治在日外国人・機関名鑑 Japan Directory 39 （1908）。ゆまに書房，東京. 立脇和夫（監修）1996s. 幕末明治在日外国人・機関名鑑 Japan Directory 43（1910）。氾に書房, 東京.

Thomas, O. 1905. On some new Japanese mammals presented to the British Museum by Mr. R. Gordon Smith. Annals and Magazine of Natural History 7th ser. 15: 487-495.

Thomas, O. 1906. On a second species of Lenothrix from the Liu Kiu Islands. Annals and Magazine of Natural History 7 th ser. 17: $88-89$.

Thomas, O. 1907. A new flying-squirrel from Formosa. Annals and Magazine of Natural History 7th ser. 20: 522-523.

Thomas, O. 1908a. New Asiatic Apodemus, Evotomys, and Lepus. Annals and Magazine of Natural History 8th ser. 1: $447-450$.

Thomas, O. 1908b. On the generic position of the groups of squirrels typified by "Sciurus" berdmorei and pernyi respectively, with descriptions of some new oriental species. Journal of the Bombay Natural History Society 18: 244-249.

Thomas, O. 1909. A collection of mammals from northern and central Mantchuria. Annals and Magazine of Natural History 8th ser. 4: 500-505.

Thomas, O. 1910. Three new Asiatic mammals. Annals and Magazine of Natural History, 8th Ser. 5: 534-536.

Thomas, O. 1912a. Revised determinations of two far-eastern species of Myospalax. Annals and Magazine of Natural History 8th ser. 9: 93-95.

Thomas, O. 1912b. No title. Abstract of the Proceedings of Zoological Society of London 1912: 17-18.

Thomas, O. 1912c. Two new genera and a new species of viverrine Carnivora. Proceedings of Zoological Society of London 1912: 498-503.

Thomas, O. 1912d. New species of Crocidura and Petaurista from Yunnan. Annals and Magazine of Natural History 8th ser. 9: 686-688.

Thomas, O. 1913. Four new shrews. Annals and Magazine of Natural History 8th ser. 11: 214-218.

Thomas, O. 1914. The tree-shrews of the Tupaia belangeri-chinensis group. Annals and Magazine of Natural History 8th ser. 13: 243-245.

Thomas, O. 1916. The races of Dremomys pernyi. Annals and Magazine of Natural History 8th ser. 17: 391-394.

Thomas, O. 1920. Four new squirrels of the genus Tamiops. Annals and Magazine of Natural History 9th Ser. 5: 304-308.

東京地学協会 1900. 東京地學協會記事=例會. 地学雑誌 12: 178-180.

内田清之助 1910. 數種の㮖太産鳥類に就きて. 動物学雑誌 22: 256-264.

内田清之助 1911. 硫黄島産鳥類數種に就て. 動物学雑誌 23: 535-538.

Uchida, S. 1912. A hand-list of Formosan birds. Annotationes Zoologicae Japonenses 8: 137-213.

内田清之助 1912. 千島産鳥類目録. 動物学雑誌 24: 270-280.

Ward, H. A. 1892. Preliminary notice of a new meteorite from Japan. American Journal of Science, Ser. 3, 45: 153155.

熟田善幸〈現代語訳〉2013. 韓国採集日記（1906 7年）。鳥獣採集家折居彪二郎採集日誌〜鳥学・哺乳類 学を支えた男〜 (正富宏之・加藤 克監修), pp. 73-119. 一耕社出版, 苫小牧.

渡部久吉 1896. 本年夏季に於ける三崎帝国大學臨海實駼場. 動物学雑誌 8: 383-388.

Weintraub, B. 1998. Forgotten collector of Asian animal life. National Geographic 193(6)：ページ番号なし, 巻 頭 Geographica 欄 2 ページ.

Wheeler, W. M. 1906. The ants of Japan. Bulletin of American Museum of Natural History 22: 301-328.

山崎柄根 1992. 鹿野忠雄, 台湾に魅せられたナチュラリスト. 平凡社, 東京.

山階芳麿 1948. 採集者折居彪二郎君の業績. 鳥 12: 47-53. 